\title{
11. IN SITU PETROPHYSICAL MEASUREMENTS IN THE CARIBBEAN
}

\author{
E. L. Gealy, Scripps Institution of Oceanography, University of California, La Jolla, California \\ and \\ R. D. Gerard, ${ }^{1}$ Lamont-Doherty Geological Observatory, Columbia University, New York, New York
}

\section{INTRODUCTION}

Information about the earth beneath the oceans can be derived not only from the examination and study of core samples obtained by drilling, but also by measuring some of the physical properties of these rocks in situ by instruments suspended in the drilled hole. Therefore, in 1967, before the Glomar Challenger was built, the JOIDES Planning Committee appointed an Advisory Panel on Well Logging to study the possibility of providing a means for logging holes drilled during the first nine legs of operation of the Glomar Challenger.

It was the opinion of the Advisory Panel that logging should be made an integral part of the scientific program of the Deep Sea Drilling Project because a variety of well-logging tools for the measurement of a large number of variables was commercially available, and the feasibility and scientific value of well logging had already been proven by the petroleum industry in wells drilled on land and near shore. However, since logging in deep water had not yet been accomplished, because the scientific usefulness of data on pelagic sediments derived by these means had not yet been established, and hole conditions that might exist could not be predicted, the Deep Sea Drilling Project planned that a logging feasibility study be conducted during the first several cruises of the Glomar Challenger. After abortive attempts at logging on Legs 1 and 2 a concerted effort to secure good logs was made during the last half of Leg 4. This report describes and evaluates that effort.

The authors are grateful to Gordon Campbell and to Bill Sprouse who helped in compiling the tables and in constructing the graphs and to CoLeen Speidel who typed and helped edit the manuscript.

The term "well logging" is defined as the acquisition of petrophysical information sensed by proximal devices lowered in drilled holes. Techniques and instruments for logging have been developed by the oil industry to obtain data which may permit inference of lithology over intervals in which no samples are obtained in drilled holes. Also logs, together with seismic profiles permit the inference of lithology between sites. Measurements of the physical properties on cores and in the hole make it possible to tie core samples recovered

\footnotetext{
${ }^{1}$ Lamont-Doherty Contribution No. 1558.
}

to their proper position within the stratigraphic section more accurately. Furthermore, logging can provide physical measurements which have validity only when made on rocks in situ.

\section{LITHOTYPES UNDER THE OCEANS AND CHARACTERISTICS WHICH MAY BE DETECTABLE BY LOGGING}

Although the physical characteristics of rocks as sensed by logging devices used in holes drilled on land and near shore have been studied exhaustively, information concerning the physical properties of pelagic sediments as measured by such devices only recently has begun to be accumulated. However, characteristic responses of some logs can be inferred from information about marine sediments accumulated from other sources.

Properties commonly measured by logging tools include: natural radioactivity (gamma ray), saturated bulk density, fluid content, and electrical and acoustical characteristics. Tools used on Leg 4 are described later in this chapter.

Pelagic and hemipelagic sediments, redeposited or altered sediments, volcanic ashes, mixtures of igneous materials and pelagic sediments, and oceanic basement in the strict sense, can be expected in the deep ocean basins. Near the margins of the ocean basins large deposits of sediment of terrigenous origin may be found. The properties of these sediments and the characteristics by which they might be distinguished in logging records are summarized below.

\section{Pelagic Sediments (Siliceous Oozes, Calcareous Oozes and Red Clays)}

The siliceous oozes (radiolarian ooze, diatom ooze) consist largely of silica (opal, rarely cristobalite, and converted to quartz in older sediments) in silt and sand sizes with variable admixtures of clay. Where unaltered, the porosity of these sediments is very high and grain density and saturated density are low. However, they may be diagenetically altered to chert, where the saturated bulk density approaches that of quartz:

The calcareous oozes consist mainly of nannoplankton with greater or lesser admixtures of foraminifera or pteropods. They are composed chiefly of calcite in 
clay-silt sizes. Near the surface they have a high porosity and a low saturated bulk density (but higher than that of the siliceous oozes). With depth the porosity may become quite reduced and the saturated bulk density may approach that of calcite. They may be altered to dolomite particularly if they overlie basaltic basement.

The red or brown deep sea clays appear to be of two types: 1) The first are those which contain largely terrigenous material composed mainly of kaolinite, illite and quartz with some possible amorphous materials, silica and cristobalite; these should be somewhat low in radioactivity. 2) The second are clays which contain largely altered volcanic materials with authigenic minerals (such as zeolites), and which tend to be low in kaolin and quartz. The porosity is very high at the surface and decreases with depth. The clays show enrichment in iron minerals (oxides) and in manganese minerals (oxides and carbonates); this enrichment may cause the clays to have a grain density as high as 3.0. In stratified sequences calcareous sediments should show a higher saturated bulk density than the interbedded clays.

The radioactivity of the pelagic sediments is largely a function of the potassium content $\left(\mathrm{K}^{40}\right)$. Most of the potassium in marine sediments occurs in the clays where it should range from about 2.0 to 2.5 per cent. Zeolites contain up to $5.6 \mathrm{~K}_{2} \mathrm{O}$, and materials containing them should be moderately radioactive. Siliceous and calcareous components tend to dilute the clay and sediments containing them show lower radioactivity. Glauconite contains 4.0 to 8.0 per cent potassium and contributes to the radioactivity of sediments in which it is abundant. Some pelagic sediments are rich in organic debris containing abundant uranium and thorium and should show as horizons of higher radioactivity particularly at unconformities or at horizons of very slow accumulation.

Ferromanganese nodules accumulate uranium (14 to $13 \mathrm{ppm}$ ) and thorium ( 3 to $150 \mathrm{ppm}$ ) and beds containing them should be radioactive.

\section{The Redeposited Sediments}

The redeposited sediments found on the slopes and rises are chiefly laminite muds and silts of terrigenous origin. In places these may take the form of redeposited carbonates derived from the shelf. Also to be included in this group are the pebbly mudstones emplaced by mudflows off the continental slope. Sediments derived from continental sources may contain hydro-micas which contain 3.0 to 6.0 per cent potassium and, therefore, will be radioactive.

On the abyssal plains there are turbidites and sand silts redeposited from sources on the shelf, slope and rise and from other localities on the abyssal plain. These turbidites range from quartz-rich terrigenous sands and silts to biogenic calcarenites from the shelf. Intermediate turbidites commonly contain glauconite, which shows higher radioactivity. Turbidite sands usually show poor sorting and have lower porosity and higher saturated bulk density than "clean" sands. The graded character of the thick turbidites may be detectable on electric logs. The turbidite sequences with their alternating layers of coarser and finer materials, more permeable and less permeable, clay-poor and clay-rich, carbonate-poor and carbonate-rich should be easily distinguishable on log suites.

\section{Volcanic Ashes}

Ashes in various stages of alteration are commonly found. Unaltered basaltic ash should be low in potassium and, therefore, show low radioactivity. Altered basaltic ashes, however, contain zeolites, rich in potassium (particularly phillipsite) and, therefore, are more radioactive. Unaltered acidic ashes are high in potassium and may contain enough uranium to make them strongly radioactive.

\section{Igneous Rocks}

The uppermost igneous material encountered in the deep oceans is likely to be basaltic and intercalated with pelagic sediments. The basaltic material is commonly spilitic and may be irregularly chloritized to greenstone. Oceanic basement, in the strict sense, may consist of two rock types: 1) ultramafics, probably peridotites, dunites, and serpentinites, and, 2) mafic complexes of gabbro and diabase. Basement rock should show very high bulk density, negligible porosity, very high resistivity and variable radioactivity.

\section{Terrigenous Sediments}

Voluminous masses of terrigenous materials (quite distinct from the abyssal laminites and turbidites referred to above), for example, the paraglacial mudstone sequences found at Site 1, Leg I of the Deep Sea Drilling Project, may be found on the slopes and rises, and, their petrophysical characteristics may resemble those sediment sequences penetrated near shore and on which there is a substantial literature.

\section{Regional Considerations}

Some information available from well logs may relate to regional, rather than depositional characteristics of the rocks penetrated. For example, orthoclase which is high in potassium may be abundant near areas of vulcanism and produce regions of higher radioactivity.

Unconformities may be more radioactive than the underlying material because phosphate minerals from fish debris tend to accumulate here. Beds near the Miocene-Eocene boundary at Site 29 (discussed in the following section) for instance, which are sixteen times 
as radioactive as the underlying Eocene and twice as radioactive as the overlying Miocene may be examples of this phenomena.

Complexly layered stratigraphy due to regional changes in the pelagic sediment rain and wide spreading of individual turbidity currents on abyssal plains should be susceptible to detailed correlation by electric logs.

\section{LOGGING OPERATIONS, LEG 4}

Logging tools and peripheral equipment were placed on board the Glomar Challenger at San Juan, Puerto Rico, March 1969. Jack Hurst of Schlumberger OffShore Services and F. M. Purcell of Grice Ocean Engineering Inc. boarded the Challenger at Puerto Rico and operated the logging equipment on the remainder of Leg 4.

Logs were obtained by using probes lowered in the drilled hole on a multi-conductor cable which transmitted signals to the ship for recording. The down-hole assembly used in drilling and logging operations on the latter part of Leg 4 is shown in Table 1. The logging tools on board the Glomar Challenger on Leg 4 are listed in Table 2.

On Leg 4, successful use was made of the gamma ray tool, the neutron tool, and the electrical survey tool (all Schlumberger), the capabilities of which are summarized below.

The gamma ray tool records the natural radioactivity of the rocks penetrated. The tool consists of an eight inch scintillation counter with an electronic cartridge powered from the surface. The cartridge supplies voltage to the counter to shape and amplify the pulses and transmit them to the surface. At the surface, the pulse rate is converted into voltage and the voltage is recorded
TABLE 1

Down-Hole Assembly Used in Drilling and Logging Operations at Sites 28 and 29

\begin{tabular}{clrc}
\hline $\begin{array}{c}\text { Reference } \\
\text { No. on } \\
\text { Schematic }\end{array}$ & \multicolumn{1}{c}{ Equipment } & $\begin{array}{r}\text { Length } \\
\text { in feet }\end{array}$ & $\begin{array}{c}\text { Length } \\
\text { in meters }\end{array}$ \\
\hline 1 & $\begin{array}{l}\text { 51/2" drill pipe } \\
2\end{array}$ & 39.96 & 12.18 \\
& $\begin{array}{l}\text { 71/4" drill collar } \\
\text { plus sub }\end{array}$ & 31.83 & 9.70 \\
3 & 81/4" drill collars (2) & 59.28 & 18.07 \\
4 & 81/4" bumper subs (2) & 43.42 & 13.23 \\
5 & 81/4" drill collars (7) & 210.65 & 64.19 \\
& plus subs & & \\
6 & Drill bit and sub & 2.15 & 0.66 \\
\hline
\end{tabular}

continuously as the sonde is pulled up the hole. A time constant for averaging counts is chosen, which is a compromise between the desire to minimize statistical fluctuations and the desire for high stratigraphic resolution.

Tools in current use are calibrated in test pits. One API unit equals $1 / 200$ th of the difference between the response of the tool operated under fixed conditions in a pit with known standard radioactivity and in a pit that is not radioactive. Formerly, tools were calibrated in radium equivalents per ton. One microgram of radium equivalent per metric ton equals approximately 11.7 API units. The following concentrations of radioactive minerals give about the same response as one microgram of radium per ton:

2.8 ppm Uranium

$3.5 \mathrm{ppm}$ Thorium

2000.0 ppm Potassium.

TABLE 2

Logging Tools Aboard the Glomar Challenger on Leg IV

Number

of Tools
Equipment

Supplier

\begin{tabular}{lll}
\hline 1 & Interval Velocity Tool & Equipment Procurement Co. \\
1 & Down-hole Accelerometer & Systron Donner Inc. \\
2 & Gamma Ray Neutron Tools & Dresser Atlas \\
2 & Caliper Tools & Dresser Atlas \\
1 & Gamma Ray-Gamma Gamma Tool & Schlumberger \\
1 & Electrical Survey Tool & Schlumberger \\
1 & Maximum Reading Thermometer & Schlumberger \\
1 & Gamma Ray Neutron Tool & Schlumberger \\
\hline
\end{tabular}


The neutron tool used aboard the Glomar Challenger consists of an americum-beryllium source of fast neutrons placed about 15 inches from a detector sensitive to both high energy captured gamma rays and thermal neutrons. As the emitted neutrons pass through the rock, they collide with other nuclei losing momentum until they reach the thermal velocity of the atomic nuclei of the surrounding material. When so slowed, they may be absorbed by surrounding nuclei and this absorption results in the emission of gamma rays which can be detected by the counter.

The number of gamma rays emitted is related to the number of neutrons absorbed, but only those emitted near the counter are detected and recorded. Hydrogen, having a mass almost equal to the neutrons, is most effective in slowing down the neutrons.

For practical purposes, the neutron tool can be considered to respond to the hydrogen content of the rock. In the presence of relatively large amounts of hydrogen, most of the neutrons will be slowed and captured in the immediate vicinity of the neutron source.

If the rock is relatively free of hydrogen, the neutrons have a greater chance of reaching the rock near the detector where either the captured gamma rays resulting from their absorption or the neutrons themselves can be counted by the detector. Therefore, a high counting rate indicates that relatively few of the neutrons were impeded in their transmission and, thus, the hydrogen content of the rock is low. Conversely, a low counting rate implies a high hydrogen content.

The response of the neutron tool depends not only on the characteristics of the rock penetrated but on the design of the tool (including its diameter, the nature of the source, and the distance between the source and the detector), on the diameter of the hole and on the nature of the fluid in the hole.

The neutron tools used are calibrated in test pits maintained by the American Petroleum Institute. The pits have known lithology, porosity, and fluid content, and empirically derived departure curves are available for the interpretation of records produced by the tools (Dewan, 1956). In general, it can be considered that the neutron tool used here responds as follows, when the logs are properly corrected:

$$
\begin{aligned}
1680 \mathrm{API} \text { units } & \approx 2 \text { per cent water content } \\
1000 \mathrm{API} \text { units } & \approx 19 \text { per cent water content } \\
640 \mathrm{API} \text { units } & \approx 40 \text { per cent water content } \\
370 \mathrm{API} \text { units } & \approx 100 \text { per cent water content }
\end{aligned}
$$

The electrical survey tool used aboard the Glomar Challenger measures both the spontaneous potential and resistivity.
The spontaneous-potential $\log$ responds to minute currents that flow in the borehole both as a result of dissimilarities between the borehole fluid and the interstitial fluid in the rocks and as a result of differences in the electrical quality of the sediments, these differences being related to lithologic differences. It is recorded in millivolts.

The resistivity tool used consists of a conventional resistivity-measuring electrode arrangement wherein a known potential is applied to a source electrode, and the potential difference between other electrodes suspended at known fixed distances from it is recorded in ohm-meters. The potential difference is a function of the resistivity of the formation separating the electrodes. The resistivity log in the sedimentary materials expected should respond primarily to the amount, ionic content and distribution of interstitial fluid in the rocks.

\section{OPERATIONS SUMMARY}

The first hole logged on Leg 4 was at Site 28 where, using Schlumberger equipment, a technically successful in-pipe gamma-ray log was made through the entire sediment section. It was decided not to run additional logs because of time. At Site 29, successful open hole gamma-ray, neutron and electric logs were made. An attempt was made to run the gamma ray-gamma gamma $\log$ at Site 29, but the electronic system required repairs and the attempt was abandoned. At Site 30, a positioning beacon failed before completion of drilling and no logging was attempted. At Site 31 the sand line parted, plugging the pipe and prevented an in-hole logging attempt. However, after all of the pipe had been retrieved, the ES sonde was lowered through the moon pool into the sea and to a depth of 300 meters, and the water column was logged.

Measurements made at Sites 28,29 and 31 are described below. Since these logging measurements are among the first ever obtained in deep ocean sediments, the interpretations and correlations given in this discussion must be considered to be of a preliminary nature.

\section{Site 28}

Drilling and coring operations at Site 28 ended at noon on March 6, having penetrated to a depth of 404 meters (1326 feet) below ocean bottom, the deepest sample being sediment of Cenomanian age. Cores recovered are summarized in Table 3. Core recovery below 175 meters (574 feet) had been so poor that logging information on the deeper beds was strongly desired to help in interpreting the drilling results. The plan was to take an in-pipe log, using the gamma-ray-neutron tool, and then obtain an open-hole log using the same equipment.

Accordingly, at 1400 hours the logging operation began. The hole was filled with mud before lowering the sonde. The drill bit was raised 13 meters (43 feet) above the 
TABLE 3

Cores Recovered from Site 28

Lat. $20^{\circ} 35.19^{\prime} \mathrm{N}$, Long. $65^{\circ} 37.33^{\prime} \mathrm{W}$

(Using a Diamond Bit)

\begin{tabular}{|c|c|c|c|c|c|}
\hline Core & $\begin{array}{l}\text { Drill String } \\
\text { (meters) }\end{array}$ & $\begin{array}{l}\text { Penetration } \\
\text { (meters) }\end{array}$ & $\begin{array}{l}\text { Core } \\
\text { Recovered } \\
\text { (meters) }\end{array}$ & Lithology & Age \\
\hline 1 & $5593-5603$ & $59-68$ & 0.0 & $\begin{array}{l}\text { Recovery: } 1 \text { cc of nonfossiliferous, } \\
\text { brown beige, zeolitic clay. }\end{array}$ & \\
\hline 2 & $5603-5612$ & $68-77$ & 4.6 & $\begin{array}{l}\text { Varigated green-gray, brown, and } \\
\text { red clay; dolomite, mica, zeolites } \\
\text { and feldspar. }\end{array}$ & $\begin{array}{l}\text { No nannofossils, Radio- } \\
\text { laria, or foraminifera }\end{array}$ \\
\hline 3 & $5703-5710$ & $169-176$ & 7.6 & $\begin{array}{l}\text { Green-gray clay with nannofossils, } \\
\text { sponge spicules, Radiolaria, mica } \\
\text { and diatoms, chert. }\end{array}$ & Upper Middle Eocene \\
\hline 4 & $5710-5720$ & $176-185$ & 0.5 & $\begin{array}{l}\text { Green-gray clay with nannofossils, } \\
\text { Radiolaria, sponge spicules, foram- } \\
\text { inifera. }\end{array}$ & Lower Middle Eocene \\
\hline 5 & $5770-5779$ & $236-245$ & 0.3 & White nannofossil clay ooze. & Lower Middle Eocene \\
\hline 6 & $5810-5814$ & $276-280$ & 0.0 & (Brown zeolitic clay?) & (Lower Middle Eocene?) \\
\hline 7 & $5814-5817$ & $280-283$ & 0.3 & Gray nannofossil chalk. & Lower Middle Eocene \\
\hline 8 & $5879-5888$ & $345-354$ & 0.3 & $\begin{array}{l}\text { Mixed rock fragments from core } \\
\text { catcher: white sugary chalk; white } \\
\text { nannofossil clay; red radiolarian } \\
\text { argillite; green banded clay; brown } \\
\text { banded clay; brown claystone with } \\
\text { dolomite; blue claystone with car- } \\
\text { bonate; pink claystone with Radio- } \\
\text { laria; brown radiolarian siliceous } \\
\text { clay; yellow clay with carbonate. }\end{array}$ & Lower Middle Eocene \\
\hline 9 & 5934-5938 & $400-404$ & 0.3 & $\begin{array}{l}\text { Green-gray clay with pyrite, } \\
\text { quartz, zeolites, chlorite and cal- } \\
\text { cite. }\end{array}$ & Lower Upper Cretaceous \\
\hline
\end{tabular}

bottom of the hole ( 404 meters below the ocean bottom), and the logging tools were lowered through the drill bit to the bottom of the hole. Open-hole gamma ray-neutron measurements were obtained in the bottom 13 meters, and in-pipe logs were obtained in the upper 357 meters (1171 feet) of the hole between the drill bit and the ocean bottom. The sonde was raised at a rate of 6 meters (20 feet) per minute. Figure 1 shows a schematic of the logging operation at Site 28. The tools used in the down-hole assembly are listed in Table 2.

An in-pipe gamma ray-neutron log of good technical quality was made throughout the entire sediment column (Figure 2). The signal, particularly the neutron signal, is greatly attenuated by the drill string. The drill collars connecting the joints are detectable on the gamma-ray log and are so prominent on the neutron $\log$ as to obscure the signal. The lower portion of the record, taken inside the 8.25 -inch drill collars used to weight the drill bit, shows even further attenuation, the signal being only one-third of the value measured in the 5.5-inch pipe section.

The neutron log showed no obvious patterns and was characterized by a "noisy" record punctuated by large "spikes" toward low values marking the location of each joint collar in the drill pipe.

The in-pipe gamma-ray record is more useful. It clearly shows that the upper 45 meters of sediment are markedly more radioactive than the underlying materials. The radioactivity decreases from 48 to 30 A.P.I. units within this interval. At about 24 meters, a thin bed (less than two meters thick) reaches a maximum of 105 A.P.I. units. 


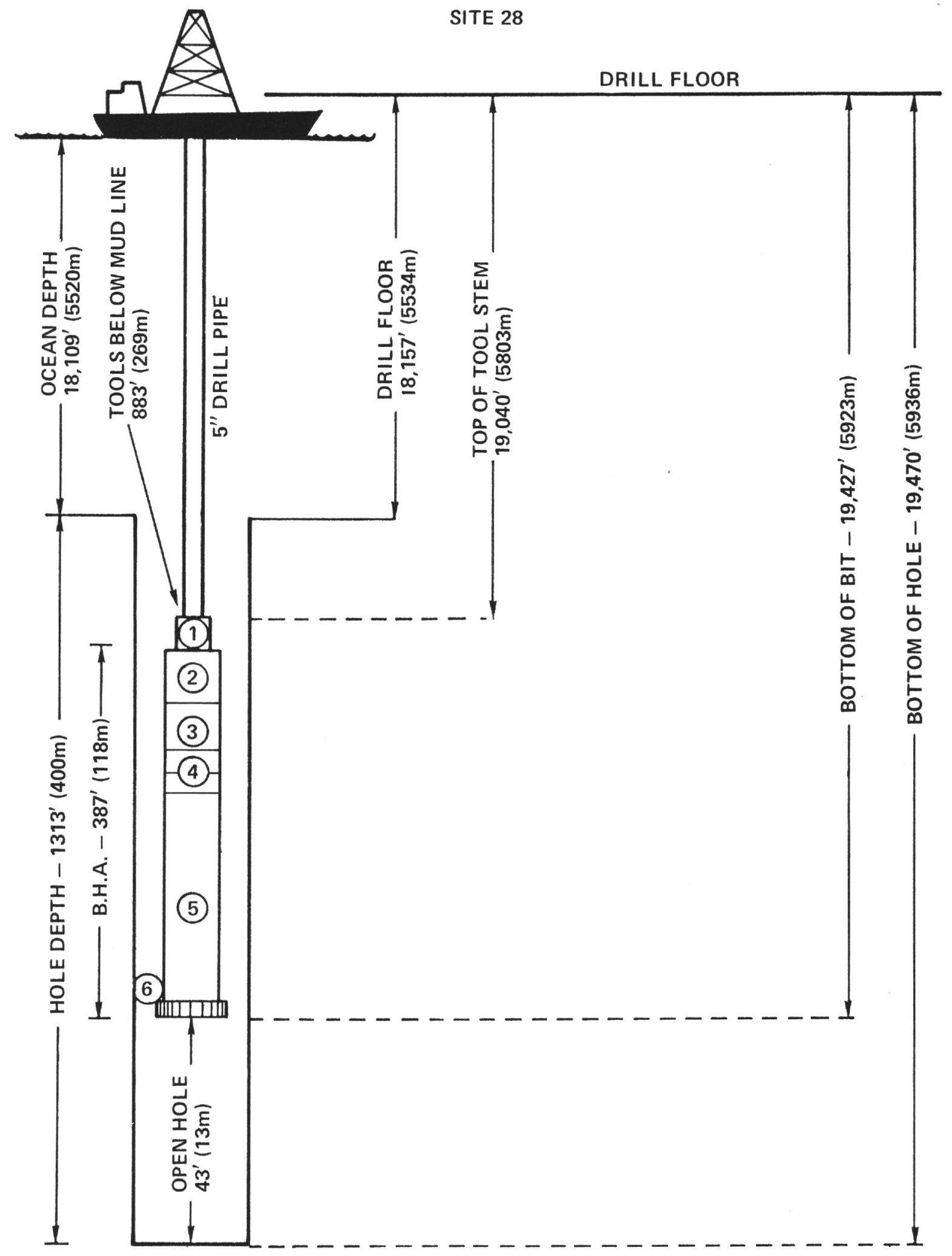

Figure 1. Schematic of operation at Site 28 for in-pipe Gamma Ray and Neutron logging, 6 March 1969. Numbers shown on down-hole assembly refer to items listed in Table 1. 


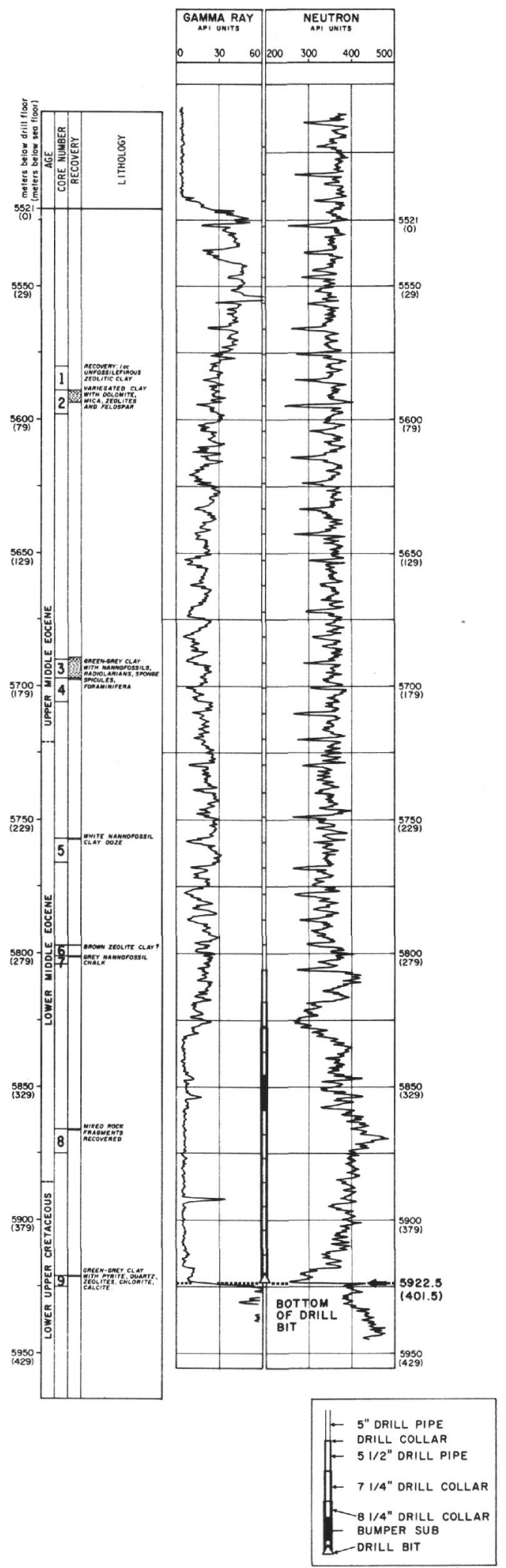

Figure 2. Relationship between lithology of cores and in-hole logs at Site 28. 
The interval from 45 meters to 160 meters consists of beds of more and less radioactive material but, overall, shows a gradual decrease in radioactivity from 30 to 18 A.P.I. units. Core 2, at about 70 meters, sampled a relatively pure Middle Eocene pelagic clay containing zeolites. Core 3 at about 170 meters also contained Middle Eocene pelagic clay, but the calcium carbonate content was as high as 25 per cent in some samples. The gradual decrease in radioactivity observed may be due, in part, to the increase in calcium carbonate between these samples which would tend to dilute the more radioactive clays, and, in part, to a decrease in the zeolite content which would serve to decrease the radioactivity even further.

The interval between 160 and 240 meters records a gradual increase in radioactivity from 18 to 24 A.P.I. units which may reflect a decrease in calcium carbonate content.

There is an abrupt decrease in radioactivity (to an average of 18 A.P.I. units) at 240 meters which may mark the top of the Lower Middle Eocene calcareous ooze sampled by Core 5 (up to 75 per cent calcium carbonate) and by Core 7 .

The entire interval between 75 and 300 meters (below which the radiation is strongly absorbed by the drill collars) also appears to consist of alternating layers of more and less radioactive material.

The alternation of more and less radioactive beds noted at this site may correspond to the acoustically "semitransparent" banded sediment indicated below 175 meters by the seismic reflection records discussed in the chapter of this volume summarizing results at Site 28 .

The bottom 16 meters (from 397 to 413) were logged in the open hole. This interval contains three beds showing a maximum of 66 A.P.I. units in contrast to 6 A.P.I. units measured through the drill collars and 18 A.P.I. units in the drill pipe for, presumably, similar materials. It may be concluded that in-pipe natural gamma-ray logs may be useful in recording strong changes in the radioactive content of the deep sea sediment, but similarly obtained neutron logs are of little value.

\section{Site 29}

Site 29 was drilled in 4247 meters of water in the central part of the Venezuela Basin in order to recover a complete stratigraphic record of the Tertiary and older strata which might be present, and to determine the age and nature of the reflecting horizons " $A$ " and "B". A hard middle Eocene chert at about 225 meters below the mudline proved to be impossible to penetrate.

Thirty-eight cores were obtained in four holes at Site 29 in an attempt to achieve continuous sampling, and a summary of the cores recovered is given in Table 4. It is estimated that approximately 83 meters of section were sampled, or 34 per cent of the sediment penetrated by the deepest hole.

After completion of the drilling at Hole $29 \mathrm{C}$, logging operations were begun at 2010 hours on March 13, 1969. The first logs (29-A), using the gamma rayneutron tools, were run with the drill bit raised 50 meters (163 feet) above the bottom of the hole. Figure 3 shows schematically the operational set-up. Following the first run, the drill string was raised so that the bit was held at 150 meters (492 feet) above bottom. A second run (29-B) from the bottom of the hole was made using the same logging tools and was completed by 0500 hours on March 14. Figure 4 shows a schematic view of this operation. In both cases the sonde was raised at a rate of 6 meters (20 feet) per minute.

The gamma-ray, neutron and electrical logs obtained at this site are reproduced in Figure 5, together with shipboard laboratory measurements of physical properties which are plotted on a corresponding vertical scale.

\section{Correlation of Physical Properties Measured on Cores and in situ}

Data available from cores and logs at Site 29 permit good definition of some in situ petrophysical characteristics of the marine sediments.

Measurements of natural gamma radiation, saturated bulk density (by gamma-ray attenuation and section weight), porosity (by gamma-ray attenuation and water content), thermal conductivity, carbonate content and grain-size were made on most sections by methods described elsewhere in this volume. Averaged values per section of some of these parameters for sediments recovered in the interval where open-hole logs were obtained are listed in Table 5 together with mean values of the in-hole natural gamma-ray and neutron logs. For more detailed information and for information about the physical properties of other intervals, reference is made to earlier chapters in this volume.

On Table 5 the gamma-ray (core) values are in counts per 1.25 minutes for a sediment volume 3 inches in length and 2.5 inches in diameter. To avoid "end" effects the first two and last two values measured on each section were deleted and the remaining sixteen values averaged. With respect to the carbonate content a value of 0.0 means that no carbonate was detected, and (-) indicates that no measurement was made; in all cases the values represent a single measurement.

In most cases values of saturated bulk density are derived from gamma-ray attenuation measurements of the full 2.5-inch diameter cores, calibrated with standards of sea water and of aluminum. All values in each section 
TABLE 4

Cores Recovered from Site 29

Lat. $14^{\circ} 47.11^{\prime} \mathrm{N}$, Long. $69^{\circ} 19.36^{\prime} \mathrm{W}$

(Using a Tungsten Carbide Bit)

\begin{tabular}{|c|c|c|c|c|c|}
\hline \multicolumn{6}{|c|}{ Hole 29} \\
\hline Core & $\begin{array}{l}\text { Drill String } \\
\text { (meters) }\end{array}$ & $\begin{array}{l}\text { Penetration } \\
\text { (meters) }\end{array}$ & $\begin{array}{l}\text { Core } \\
\text { Recovered } \\
\text { (meters) }\end{array}$ & Lithology & Age \\
\hline 1 & $4284-4293$ & $0-9$ & 4.6 & $\begin{array}{l}\text { Nannoplankton/foraminifera clay ooze } \\
\text { ( } 0 \text { to } 4.56 \text { meters); foraminifera/nan- } \\
\text { noplankton chalk ooze ( } 4.56 \text { to } 9 \text { me- } \\
\text { ters). }\end{array}$ & Recent-Pleistocene \\
\hline 2 & $4293-4302$ & $9-18$ & 4.6 & $\begin{array}{l}\text { Foraminifera / nannoplankton chalk } \\
\text { ooze ( } 9 \text { to } 11.3 \text { meters); nannoplank- } \\
\text { ton olive clay ooze ( } 11.3 \text { to } 18 \text { meters). }\end{array}$ & $\begin{array}{l}\text { Recent-Pleistocene } \\
\text { Plio-Pleistocene }\end{array}$ \\
\hline 3 & $4302-4311$ & $18-27$ & 0.9 & $\begin{array}{l}\text { Foraminifera / nannoplankton chalk } \\
\text { ooze. }\end{array}$ & Pliocene \\
\hline 4 & $4311-4321$ & $27-37$ & 5.2 & $\begin{array}{l}\text { Nannoplankton/foraminifera, olive clay } \\
\text { ( } 27 \text { to } 32 \text { meters); olive clay ooze } \\
\text { ( } 32 \text { to } 37 \text { meters). }\end{array}$ & Pliocene \\
\hline 5 & $4321-4330$ & $37-46$ & 0.8 & Brown clay. & Non-biogenous \\
\hline 6 & $4330-4339$ & $46-55$ & 0.3 & Brown clay. & Non-biogenous \\
\hline 7 & $4401-4410$ & $117-126$ & 0.9 & $\begin{array}{l}\text { Banded white and brown marl ( } 117 \text { to } \\
124 \text { meters); radiolarian ooze/pumice, } \\
\text { ash (124 to } 126 \text { meters). }\end{array}$ & $\begin{array}{l}\text { Lower Miocene } \\
\text { Upper Eocene }\end{array}$ \\
\hline 8 & $4410-4419$ & $126-135$ & 0.9 & Radiolarian ooze/pumice, ash. & Upper Eocene \\
\hline 9 & $4419-4428$ & $135-144$ & 9.1 & Radiolarian ooze with chert chips. & Middle Eocene \\
\hline 10 & $4428-4437$ & $144-153$ & 7.6 & Radiolarian ooze. & Middle Eocene \\
\hline 11 & $4437-4446$ & $153-162$ & 0.6 & Radiolarian ooze. & Middle Eocene \\
\hline 12 & $4446-4456$ & $162-172$ & 9.1 & Radiolarian ooze. & Middle Eocene \\
\hline 13 & $4459-4468$ & $175-184$ & 0.6 & Radiolarian ooze. & Middle Eocene \\
\hline 14 & $4468-4477$ & $184-193$ & 9.1 & Radiolarian ooze. & Middle Eocene \\
\hline 15 & $4477-4486$ & $193-202$ & 9.1 & Radiolarian ooze. & Middle Eocene \\
\hline 16 & $4486-4495$ & $202-211$ & 9.1 & Radiolarian ooze. & Middle Eocene \\
\hline 17 & $4495-4504$ & $211-220$ & 9.1 & Radiolarian ooze. & Middle Eocene \\
\hline 18 & $4504-4509$ & $220-225$ & 3.7 & Radiolarian ooze. & Middle Eocene \\
\hline 19 & $4509-4510$ & $225-226$ & 0.3 & Cherty-dolomitic radiolarite. & Middle Eocene \\
\hline 20 & $4510-4513$ & $226-230$ & 0.0 & Cherty-dolomitic radiolarite. & Middle Eocene \\
\hline \multicolumn{6}{|c|}{ Hole 29A } \\
\hline Core & $\begin{array}{l}\text { Drill String } \\
\text { (meters) }\end{array}$ & $\begin{array}{l}\text { Penetration } \\
\text { (meters) }\end{array}$ & $\begin{array}{l}\text { Core } \\
\text { Recovered } \\
\text { (meters) }\end{array}$ & Lithology & Age \\
\hline 1 & $4325-4334$ & $41-50$ & 0.2 & Brown clay. & Non-biogenous \\
\hline 2 & $4334-4343$ & $50-59$ & 1.1 & $\begin{array}{l}\text { Brown clay ( } 50 \text { to } 55 \text { meters); silty } \\
\text { olive clay ( } 55 \text { to } 59 \text { meters). }\end{array}$ & Non-biogenous \\
\hline
\end{tabular}


TABLE 4 - Continued

\begin{tabular}{|c|c|c|c|c|c|}
\hline \multicolumn{6}{|c|}{ Hole 29A } \\
\hline Core & $\begin{array}{l}\text { Drill String } \\
\text { (meters) }\end{array}$ & $\begin{array}{l}\text { Penetration } \\
\text { (meters) }\end{array}$ & $\begin{array}{c}\text { Core } \\
\text { Recovered } \\
\text { (meters) }\end{array}$ & Lithology & Age \\
\hline 3 & $4343-4352$ & $59-68$ & 0.3 & $\begin{array}{l}\text { Silty olive clay ( } 59 \text { to } 65 \text { meters); } \\
\text { brown clay, feldspar ( } 65 \text { to } 68 \text { meters). }\end{array}$ & Non-biogenous \\
\hline 4 & $4352-4361$ & $68-77$ & 0.9 & $\begin{array}{l}\text { Brown clay, feldspar ( } 68 \text { to } 69 \text { meters); } \\
\text { banded mica clay ( } 69 \text { to } 77 \text { meters). }\end{array}$ & Middle Miocene \\
\hline 5 & $4361-4370$ & $77-86$ & 0.9 & $\begin{array}{l}\text { Silty olive clay ( } 77 \text { to } 80 \text { meters); } \\
\text { brown clay ( } 80 \text { to } 86 \text { meters). }\end{array}$ & $\begin{array}{l}\text { Middle Miocene } \\
\text { Non-biogenous }\end{array}$ \\
\hline \multicolumn{6}{|c|}{ Hole 29B } \\
\hline Core & $\begin{array}{l}\text { Drill String } \\
\text { (meters) }\end{array}$ & $\begin{array}{l}\text { Penetration } \\
\text { (meters) }\end{array}$ & $\begin{array}{c}\text { Core } \\
\text { Recovered } \\
\text { (meters) }\end{array}$ & Lithology & Age \\
\hline 1 & $4341-4350$ & $57-66$ & 9.1 & Silty olive clay and brown clay. & Non-biogenous \\
\hline 2 & $4352-4361$ & $68-77$ & 4.9 & $\begin{array}{l}\text { Brown clay-feldspar; } \\
\text { banded mica clay. }\end{array}$ & $\begin{array}{l}\text { Non-biogenous } \\
\text { Middle Miocene }\end{array}$ \\
\hline 3 & $4362-4371$ & $78-87$ & 3.0 & $\begin{array}{l}\text { Silty olive clay; } \\
\text { brown clay. }\end{array}$ & $\begin{array}{l}\text { Middle Miocene } \\
\text { Non-biogenous }\end{array}$ \\
\hline 4 & $4371-4381$ & $87-97$ & 6.4 & Brown clay. & Non-biogenous \\
\hline 5 & $4381-4390$ & $97-106$ & 6.1 & White to gray marl. & Lower Miocene \\
\hline 6 & $4390-4399$ & $106-115$ & 0.6 & White to gray marl. & Lower Miocene \\
\hline 7 & $4399-4408$ & $115-124$ & 0.15 & Banded white and brown marl. & Lower Miocene \\
\hline 8 & $4408-4417$ & $124-133$ & 9.1 & Radiolarian ooze/pumice, ash. & Upper Eocene \\
\hline 9 & $4502-4511$ & $218-227$ & 9.1 & $\begin{array}{l}\text { Radiolarian ooze; radiolarian ooze with } \\
\text { pumice. }\end{array}$ & Middle Eocene \\
\hline 10 & $4511-4515$ & $227-231$ & 4.0 & $\begin{array}{l}\text { Radiolarian ooze with pumice; cherty } \\
\text { dolomitic radiolarite. }\end{array}$ & Middle Eocene \\
\hline \multicolumn{6}{|c|}{ Hole $29 \mathrm{C}$} \\
\hline Core & $\begin{array}{l}\text { Drill String } \\
\text { (meters) }\end{array}$ & $\begin{array}{l}\text { Penetration } \\
\text { (meters) }\end{array}$ & $\begin{array}{c}\text { Core } \\
\text { Recovered } \\
\text { (meters) }\end{array}$ & Lithology & Age \\
\hline 1 & $4513-4520$ & $230-236$ & 0.80 & Cherty dolomitic radiolarite. & Middle Eocene \\
\hline 2 & $4520-4526$ & $236-242$ & 0.50 & Cherty dolomitic radiolarite. & Middle Eocene \\
\hline 3 & $4526-4532$ & $242-248$ & 0.08 & Cherty dolomitic radiolarite. & Middle Eocene \\
\hline
\end{tabular}




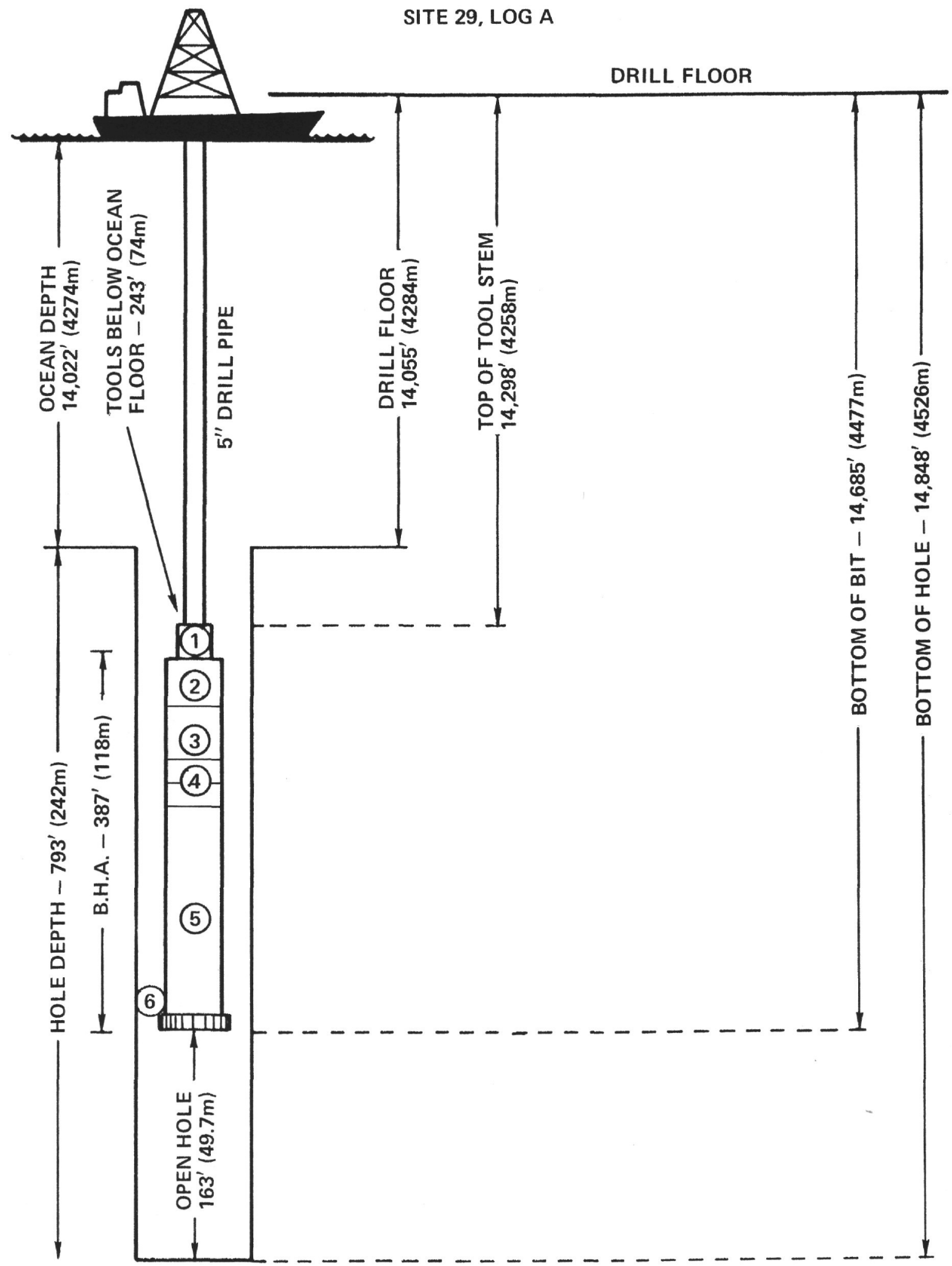

Figure 3. Schematic of operation at Site 29, Hole C, Log A, for Gamma Ray, Neutron and Electrical logging, 13 March 1969. Numbers on down-hole assembly refer to items listed in Table 1. 


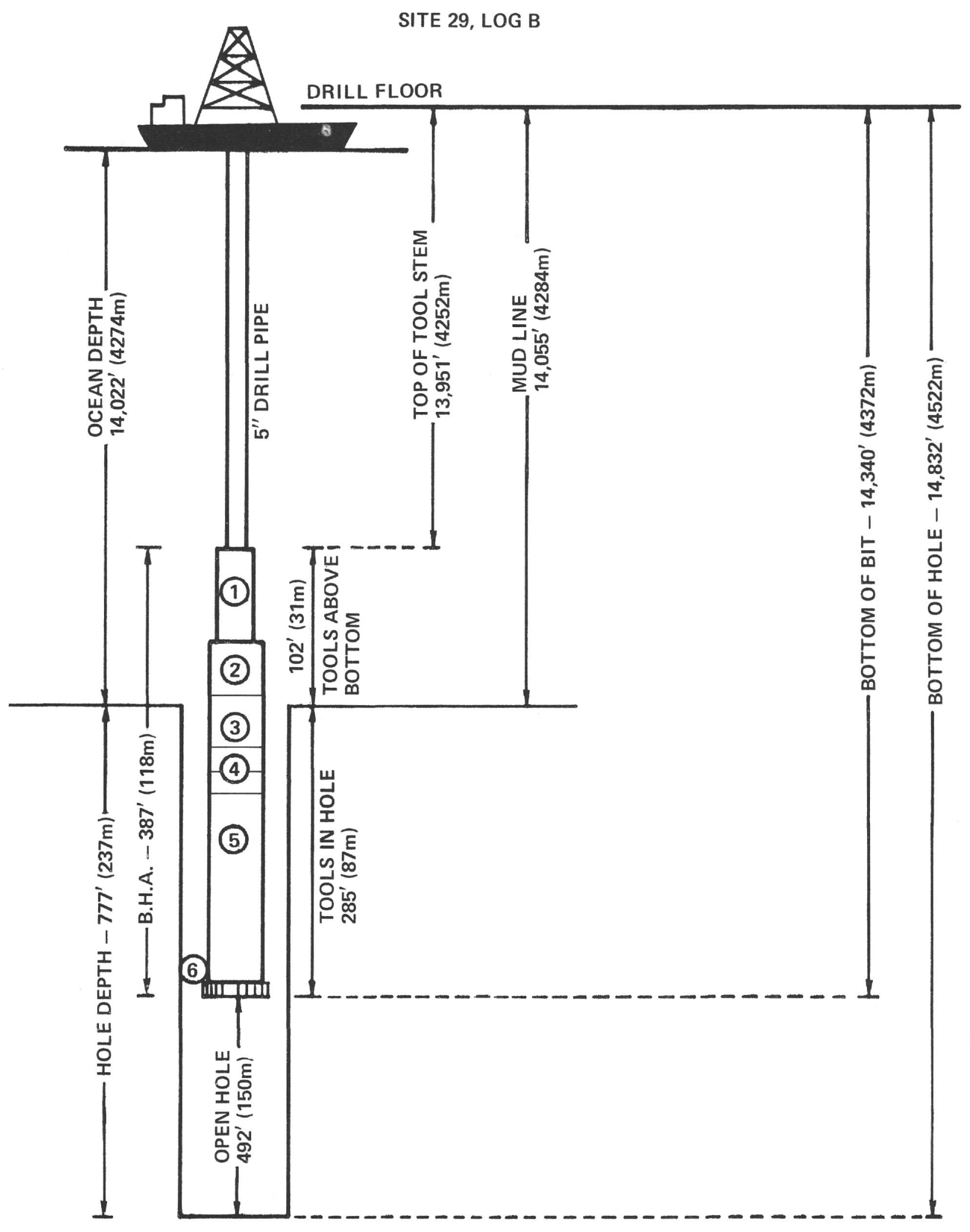

Figure 4. Schematic of operation at Site 29, Hole C, Log B, for Gamma Ray, Neutron and Electrical logging, 14 March 1969. Numbers on down-hole assembly refer to items listed in Table 1. 


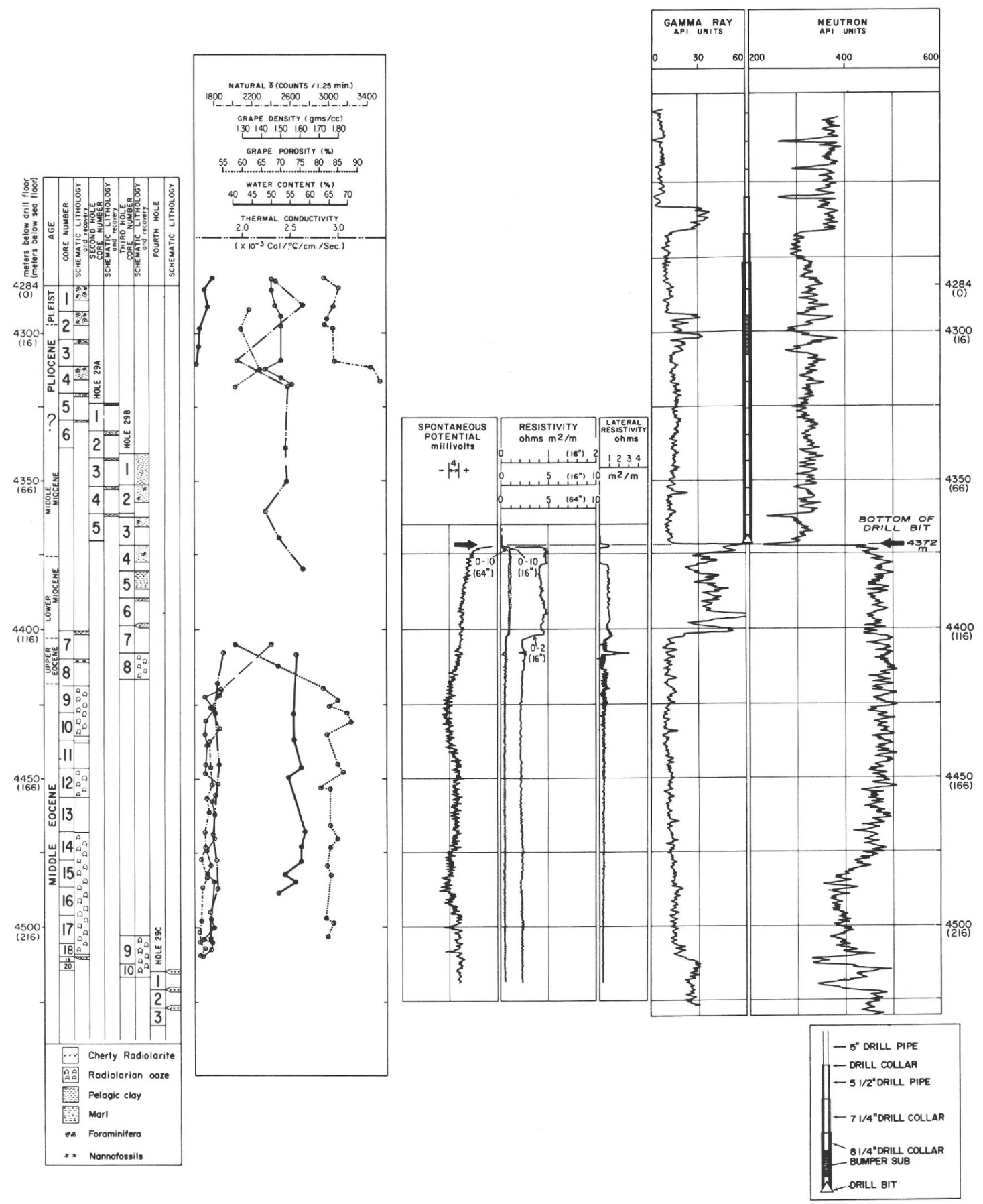

Figure 5. Relationship between physical properties and lithology of cores and in-hole logs at Site 29. 
TABLE 5

Summary of Physical Properties, Site 29

\begin{tabular}{|c|c|c|c|c|c|c|c|c|c|c|c|c|}
\hline Hole & Core & Section & $\begin{array}{r}\text { Interval } \\
\text { (meters) }\end{array}$ & $\begin{array}{c}\text { (Core) } \\
\text { Gamma Ray } \\
\text { Ave/Sec } \\
\text { (counts } / 3^{\prime \prime} / 1.25 \mathrm{sec} \text { ) }\end{array}$ & $\begin{array}{c}\text { (Core) } \\
\text { Carbonate } \\
\text { Ave/Sec } \\
(\%)\end{array}$ & $\begin{array}{c}\text { (Core) } \\
\text { Saturated } \\
\text { Bulk Density } \\
\left(\mathrm{gms} / \mathrm{cm}^{3}\right)\end{array}$ & $\begin{array}{c}\text { (Core) } \\
\text { Grain } \\
\text { Density } \\
\left(\mathrm{gms} / \mathrm{cm}^{3}\right)\end{array}$ & $\begin{array}{l}\text { (Core) } \\
\text { Porosity } \\
(\%)\end{array}$ & $\begin{array}{c}(\log ) \\
\text { Gamma Ray } \\
\text { Ave } / 1.5 \mathrm{~m}\end{array}$ & $\begin{array}{c}(\mathrm{Log}) \\
\text { Neutron } \\
\text { Ave } / 1.5 \mathrm{~m}\end{array}$ & $\begin{array}{c}\phi \mathrm{N} \\
\text { Calculated } \\
\text { Neutron Porosity }\end{array}$ & $\begin{array}{c}\left(\phi_{C}-\phi_{N}\right) \\
\Delta \phi\end{array}$ \\
\hline \multirow[t]{4}{*}{$29 B$} & 4 & 1 & $(87-97)$ & 2882 & 0.0 & 1.51 & 2.65 & 70.1 & 57 & 470 & 62.5 & 7.6 \\
\hline & & 2 & & 3094 & 0.0 & 1.56 & 2.65 & 67.0 & 54 & 490 & 60.6 & 6.4 \\
\hline & & 3 & & 3150 & 0.0 & 1.65 & 2.65 & 61.5 & 33 & 490 & 60.6 & 0.9 \\
\hline & & 4 & & 2891 & 0.0 & 1.66 & 2.65 & 60.9 & 42 & 470 & 62.5 & -1.6 \\
\hline \multirow[t]{4}{*}{ 29B } & 5 & 1 & $(97-106)$ & 2473 & 1.1 & 1.54 & 2.65 & 68.3 & 36 & 460 & 63.6 & 4.7 \\
\hline & & 2 & & 2022 & 52.7 & 1.61 & 2.68 & 64.6 & 39 & 483 & 61.0 & 3.6 \\
\hline & & 3 & & 2299 & 42.2 & 1.62 & 2.68 & 64.0 & 35 & 481 & 61.1 & 2.9 \\
\hline & & 4 & & 2467 & 21.0 & 1.55 & 2.70 & 68.6 & 41 & 450 & 64.8 & 3.8 \\
\hline 29B & 6 & 1 & $(106-115)$ & & & $1.38 \mathrm{~W}^{1}$ & & & & 480 & & \\
\hline 29 & 7 & & $(117-126)$ & & & & 2.30 & & & 490 & & \\
\hline \multirow[t]{6}{*}{$29 B$} & 8 & 1 & $(124-133)$ & 1764 & 0.0 & $1.29 \mathrm{~W}$ & 2.13 & 75.9 & 12 & 482 & 61.2 & 14.7 \\
\hline & & 2 & & 1857 & 0.0 & 1.41 & 2.13 & 65.1 & 12 & 500 & 59.5 & 5.6 \\
\hline & & 3 & & 1887 & 0.0 & 1.27 & 2.04 & 75.8 & 12 & 482 & 61.2 & 14.6 \\
\hline & & 4 & & 1691 & 0.0 & 1.27 & 2.02 & 75.3 & 11 & 482 & 61.2 & 14.1 \\
\hline & & 5 & & 1692 & 0.0 & 1.28 & 2.01 & 74.0 & 11 & 490 & 60.6 & 13.4 \\
\hline & & 6 & & 1723 & 0.0 & 1.31 & 2.04 & 71.9 & 12 & 470 & 62.5 & 9.4 \\
\hline \multirow[t]{6}{*}{29} & 9 & 1 & $(135 \cdot 144)$ & & 19.3 & 1.43 & 2.22 & 66.1 & 12 & 470 & 62.5 & 3.6 \\
\hline & & 2 & & & 0.0 & 1.26 & 1.90 & 73.1 & 15 & 470 & 62.5 & 10.6 \\
\hline & & 3 & & & 15.0 & $1.25 \mathrm{~W}$ & 2.15 & 79.9 & 13 & 500 & 59.5 & 20.4 \\
\hline & & 4 & & & 6.3 & $1.25 \mathrm{E}^{2}$ & 2.24 & 81.4 & 12 & 450 & 64.8 & 16.6 \\
\hline & & 5 & & & 0.0 & $1.25 \mathrm{E}$ & 2.31 & 82.4 & 12 & 480 & 61.4 & 21.0 \\
\hline & & 6 & & & 0.0 & $1.25 \mathrm{E}$ & 2.13 & 79.6 & 10 & 490 & 60.6 & 19.0 \\
\hline \multirow[t]{4}{*}{29} & 10 & 1 & $(144-153)$ & & 0.0 & 1.26 & 2.20 & 79.9 & 10 & 490 & 60.6 & 19.3 \\
\hline & & 2 & & & 0.0 & $1.24 \mathrm{~W}$ & 2.26 & 82.5 & 9 & 470 & 62.5 & 20.0 \\
\hline & & 3 & & & 0.0 & $1.25 \mathrm{~W}$ & 2.30 & 82.3 & 9 & 475 & 62.2 & 20.1 \\
\hline & & 4 & & & 0.0 & 1.29 & 2.25 & 78.3 & 9 & 490 & 60.6 & 17.7 \\
\hline
\end{tabular}


TABLE 5 - Continued

\begin{tabular}{|c|c|c|c|c|c|c|c|c|c|c|c|c|}
\hline Hole & Core & Section & $\begin{array}{r}\text { Interval } \\
\text { (meters) }\end{array}$ & $\begin{array}{c}\text { (Core) } \\
\text { Gamma Ray } \\
\text { Ave } / \mathrm{Sec} \\
\text { (counts } / 3^{\prime \prime} / 1.25 \mathrm{sec} \text { ) }\end{array}$ & $\begin{array}{c}\text { (Core) } \\
\text { Carbonate } \\
\text { Ave/Sec } \\
(\%)\end{array}$ & $\begin{array}{c}\text { (Core) } \\
\text { Saturated } \\
\text { Bulk Density } \\
\left(\text { gms } / \mathrm{cm}^{3}\right)\end{array}$ & $\begin{array}{c}\text { (Core) } \\
\text { Grain } \\
\text { Density } \\
\left.\text { (gms } / \mathrm{cm}^{3}\right)\end{array}$ & $\begin{array}{l}\text { (Core) } \\
\text { Porosity } \\
(\%)\end{array}$ & $\begin{array}{c}(\log ) \\
\text { Gamma Ray } \\
\text { Ave/1.5m }\end{array}$ & $\begin{array}{l}\text { (Log) } \\
\text { Neutron } \\
\text { Ave/1.5m }\end{array}$ & $\begin{array}{c}\phi \mathrm{N} \\
\text { Calculated } \\
\text { Neutron Porosity }\end{array}$ & $\begin{array}{c}\left(\phi_{\mathrm{C}}-\phi_{\mathrm{N}}\right) \\
\Delta \phi\end{array}$ \\
\hline \multirow[t]{2}{*}{29} & 10 & 5 & (144-153) & & 0.0 & 1.25 & 2.25 & 81.6 & 9 & 470 & 62.5 & 19.1 \\
\hline & & 6 & & & 0.0 & $1.25 \mathrm{E}$ & 2.25 & 81.6 & 15 & 490 & 60.6 & 21.0 \\
\hline 29 & 11 & 1 & $(157-162)$ & & 0.0 & $1.25 \mathrm{E}$ & 2.25 & 81.6 & 8 & 470 & 62.5 & 19.1 \\
\hline \multirow[t]{6}{*}{29} & 12 & 1 & $(162-172)$ & & 1.8 & 1.41 & 2.25 & 68.5 & 12 & 470 & 62.5 & 6.0 \\
\hline & & 2 & & & 0.0 & $1.26 \mathrm{~W}$ & 2.25 & 80.8 & 12 & 470 & 62.5 & 18.3 \\
\hline & & 3 & & & 6.9 & $1.27 \mathrm{~W}$ & 2.25 & 79.9 & 13 & 500 & 59.5 & 20.4 \\
\hline & & 4 & & & 11.9 & $1.32 \mathrm{~W}$ & 2.25 & 75.9 & 13 & 470 & 62.5 & 13.4 \\
\hline & & 5 & & & 14.3 & $1.30 \mathrm{~W}$ & 2.25 & 77.5 & 12 & 455 & 64.3 & 13.2 \\
\hline & & 6 & & & 15.8 & $1.26 \mathrm{~W}$ & 2.25 & 80.8 & 12 & 475 & 62.2 & 18.6 \\
\hline \multirow[t]{6}{*}{29} & 14 & 1 & (184-193) & & 0.0 & 1.29 & 2.25 & 78.3 & 13 & 462 & & \\
\hline & & 2 & & & 0.0 & 1.28 & 2.25 & 79.1 & 14 & 450 & & \\
\hline & & 3 & & & 0.0 & 1.26 & 2.25 & 80.8 & 15 & 480 & & \\
\hline & & 4 & & & 0.0 & 1.26 & 2.25 & 80.8 & 12 & 450 & & \\
\hline & & 5 & & & 0.0 & 1.28 & 2.25 & 79.1 & 14 & 440 & & \\
\hline & & 6 & & & 1.7 & 1.30 & 2.25 & 77.5 & 13 & 425 & & \\
\hline \multirow[t]{6}{*}{29} & 15 & 1 & $(193-202)$ & & 8.1 & 1.25 & 2.25 & 81.6 & 13 & 345 & & \\
\hline & & 2 & & & 15.7 & 1.30 & 2.25 & 77.5 & 14 & 390 & & \\
\hline & & 3 & & & 5.1 & 1.24 & 2.25 & 82.4 & 13 & 390 & & \\
\hline & & 4 & & & 8.0 & 1.29 & 2.25 & 78.3 & 14 & 405 & & \\
\hline & & 5 & & & 2.4 & 1.28 & 2.25 & 79.1 & 15 & 410 & & \\
\hline & & 6 & & & 9.4 & $1.25 \mathrm{~W}$ & 2.22 & 81.1 & 15 & 370 & & \\
\hline \multirow[t]{6}{*}{29} & 16 & 1 & $(202-211)$ & & 19.9 & $1.29 \mathrm{~W}$ & 2.27 & 78.7 & 15 & 400 & & \\
\hline & & 2 & & & 26.5 & $1.28 \mathrm{~W}$ & 2.21 & 78.4 & 20 & 385 & & \\
\hline & & 3 & & & 5.4 & $1.22 \mathrm{~W}$ & 2.16 & 82.7 & 16 & 380 & & \\
\hline & & 4 & & & 12.0 & $1.29 \mathrm{~W}$ & 2.30 & 79.2 & 15 & 375 & & \\
\hline & & 5 & & & 11.0 & & 2.21 & & 16 & 395 & & \\
\hline & & 6 & & & 10.4 & $1.41 \mathrm{~W}$ & 2.22 & 67.7 & 15 & 400 & & \\
\hline
\end{tabular}


TABLE 5 - Continued

\begin{tabular}{|c|c|c|c|c|c|c|c|c|c|c|c|c|}
\hline Hole & Core & Section & $\begin{array}{c}\text { Interval } \\
\text { (meters) }\end{array}$ & $\begin{array}{c}\text { (Core) } \\
\text { Gamma Ray } \\
\text { Ave } / \mathrm{Sec} \\
\text { (counts } / 3^{\prime \prime} / 1.25 \mathrm{sec} \text { ) }\end{array}$ & $\begin{array}{l}\text { (Core) } \\
\text { Carbonate } \\
\text { Ave/Sec } \\
(\%)\end{array}$ & $\begin{array}{c}\text { (Core) } \\
\text { Saturated } \\
\text { Bulk Density } \\
\left(\mathrm{gms} / \mathrm{cm}^{3}\right)\end{array}$ & $\begin{array}{l}\text { (Core) } \\
\text { Grain } \\
\text { Density } \\
\left(\mathrm{gms} / \mathrm{cm}^{3}\right)\end{array}$ & $\begin{array}{l}\text { (Core) } \\
\text { Porosity } \\
(\%)\end{array}$ & $\begin{array}{c}\text { (Log) } \\
\text { Gamma Ray } \\
\text { Ave/1.5m }\end{array}$ & $\begin{array}{l}\text { (Log) } \\
\text { Neutron } \\
\text { Ave/1.5m }\end{array}$ & $\begin{array}{c}\phi \mathrm{N} \\
\text { Calculated } \\
\text { Neutron Porosity }\end{array}$ & $\begin{array}{c}\left(\phi_{\mathrm{C}}-\phi_{\mathrm{N}}\right) \\
\Delta \phi\end{array}$ \\
\hline \multirow[t]{6}{*}{29} & 17 & 1 & $(211-220)$ & & 0.0 & 1.25 & 2.14 & 79.7 & 15 & 390 & & \\
\hline & & 2 & & & 2.0 & 1.28 & 2.08 & 75.8 & 13 & 395 & & \\
\hline & & 3 & & & 0.5 & 1.25 & 1.95 & 72.4 & 15 & 405 & & \\
\hline & & 4 & & & 0.5 & 1.27 & 2.12 & 79.4 & 15 & 380 & & \\
\hline & & 5 & & & 0.0 & 1.20 & 2.16 & 78.3 & 16 & 390 & & \\
\hline & & 6 & & & 0.0 & 1.18 & 2.15 & 84.4 & 17 & 400 & & \\
\hline \multirow[t]{6}{*}{$29 B$} & 9 & 1 & $(218-227)$ & 1634 & 8.5 & 1.28 & 2.20 & 86.7 & 15 & 380 & & \\
\hline & & 2 & & & 6.8 & $1.30 \mathrm{~W}$ & 2.24 & 78.9 & 15 & 390 & & \\
\hline & & 3 & & & 0.8 & $1.31 \mathrm{~W}$ & 2.51 & 80.8 & 16 & 400 & & \\
\hline & & 4 & & & 2.1 & $1.30 \mathrm{~W}$ & 2.27 & 77.8 & 17 & 420 & & \\
\hline & & 5 & & & 0.0 & $1.20 \mathrm{~W}$ & 2.29 & 86.1 & 15 & 460 & & \\
\hline & & 6 & & & 0.0 & $1.20 \mathrm{~W}$ & 2.22 & 85.3 & 15 & 360 & & \\
\hline \multirow[t]{3}{*}{$29 \mathrm{~B}$} & 10 & 1 & $(227-232)$ & 1619 & & 1.20 & 2.25 & 85.6 & 22 & 360 & & \\
\hline & & 2 & & 1583 & 0.0 & 1.26 & 2.25 & 80.8 & 23 & 420 & & \\
\hline & & 3 & & 1638 & 0.1 & 1.26 & 2.21 & 80.1 & 18 & 490 & & \\
\hline
\end{tabular}

${ }^{1} \mathrm{~W}=$ weighed

${ }^{2} \mathrm{E}=$ estimated 
were averaged. Where good gamma-ray attenuation data were not available, values of saturated bulk density were calculated from the weight of the section and these are marked "W". In cases where neither gammaray attenuation data nor section weights were available, the bulk density was estimated and these values are marked "E". Values of grain density are estimates based on the mineralogy of the cores and on measurements of grain density made at Naval Undersea Research and Development Center on other samples of marine sediments having similar mineralogy. Values of the average porosity per section were calculated from the saturated bulk density and estimated grain density, using an interstitial water density of 1.024 (the density of sea water at $23^{\circ} \mathrm{C}$ at one atmosphere). Obviously, the saturated bulk density and porosity do not exactly represent in situ conditions because of core disturbances which cause fluid to be either gained or lost. Values of saturated bulk density may be either lower or higher than the in situ density.

Values of neutron porosity were calculated from the neutron curve using empirical relationships between known porosity and neutron response established in the A.P.I. test pits as described earlier in this chapter.

\section{Neutron Log}

The neutron log is sensitive to the fluid in the bore hole and, because no caliper log was made, the data from the neutron $\log$ of $29 \mathrm{C}$ must be used with caution.

The low neutron values below 4480 meters, in particular those at about 4512 meters and 4419 meters, are undoubtedly a response to considerable hole enlargement produced by strong fluid circulation during attempts to penetrate the Middle Eocene cherts at the bottom of the hole. The log would indicate that a somewhat indurated bed about one meter thick at 4509 meters, a chert bed about five meters thick at 4513 meters, and a chert bed of unknown thickness at 4521 meters were penetrated. This situation is substantiated by the bottom three cores recovered which consist of alternating beds of hard cherty rock and/or porous, friable radiolarite.

The Lower Miocene noncalcareous clay section is marked by relatively high radioactivity and a high neutron porosity, which is as expected. In the underlying marl clay sequence there is poor point-by-point correlation between the neutron and gamma-ray logs. In general, a decrease in radioactivity is marked by a decrease in neutron porosity which would be logical if the beds having a lower neutron porosity were also higher in calcium carbonate content. Both of the highly radioactive beds at the base of the Lower Miocene appear to be accompanied by a slight increase in neutron porosity; this is consistent with the suggestion that they may represent brown clays.
The top of the Upper Eocene radiolarian ooze section is identifiable on the neutron log as a slight decrease in neutron porosity. This is in contrast to the porosity of the cores of radiolarian ooze which is higher in the radiolarian ooze (75 per cent) than in the overlying calcareous clays and marls (64 to 70 per cent). This apparent discrepancy may be partly due to the fact that the neutron tool responds not only to free interstitial water but also to combined $\mathrm{H}_{2} \mathrm{O}^{+}$in the clays (up to 14 per cent of the mineral component). It is also likely that the drilling process disturbed the radiolarian ooze so as to increase the core porosity. This is supported by a comparison of the values of porosity derived from measurements on the cores from 29B-4, 29B-5 and 29B-8 to 12 and the values of porosity calculated from the neutron curve (Figures 6 and 7). Values of the neutron curve below 4450 meters (Core 29B-12) appear to be increasingly influenced by hole enlargement, and have not been used in this comparison. It can be seen that the porosity of cores matches the neutron porosity in the Lower Miocene section (Cores 29B-4 and 29B-5) rather closely. The porosity of the cores in the Eocene radiolarian ooze (Core 29B-8) are consistently higher than the neutron porosities, and the difference increases roughly with increasing depth at which the cores were taken.

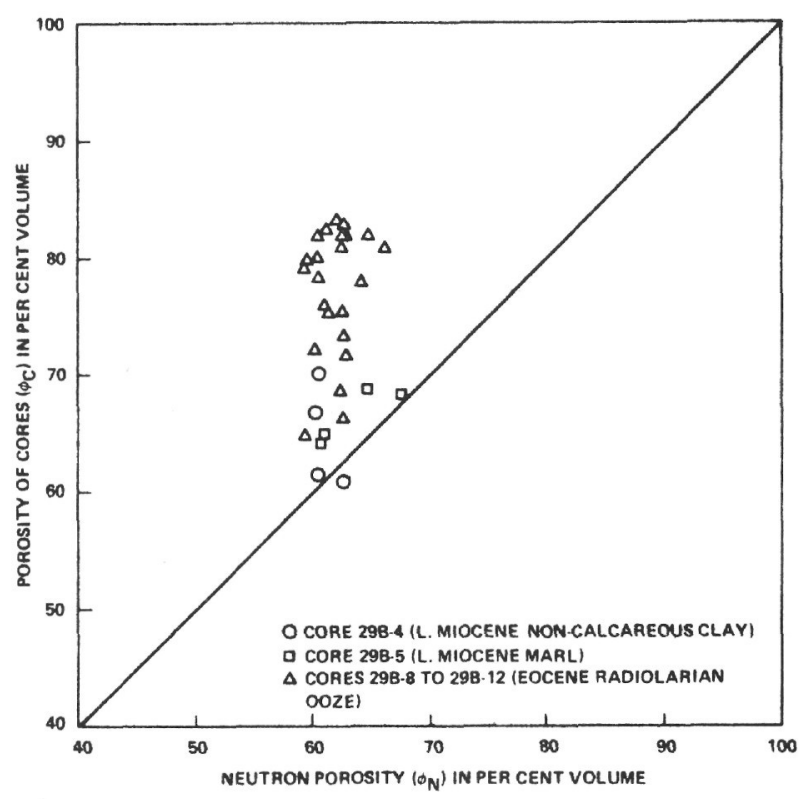

Figure 6. Relationship between porosity of cores $\left(\phi_{C}\right)$ and in situ porosity derived from Neutron $\operatorname{logs}\left(\phi_{L}\right)$ at Site 29 (Cores 29B-4, 29B-5 and 29B-8). 


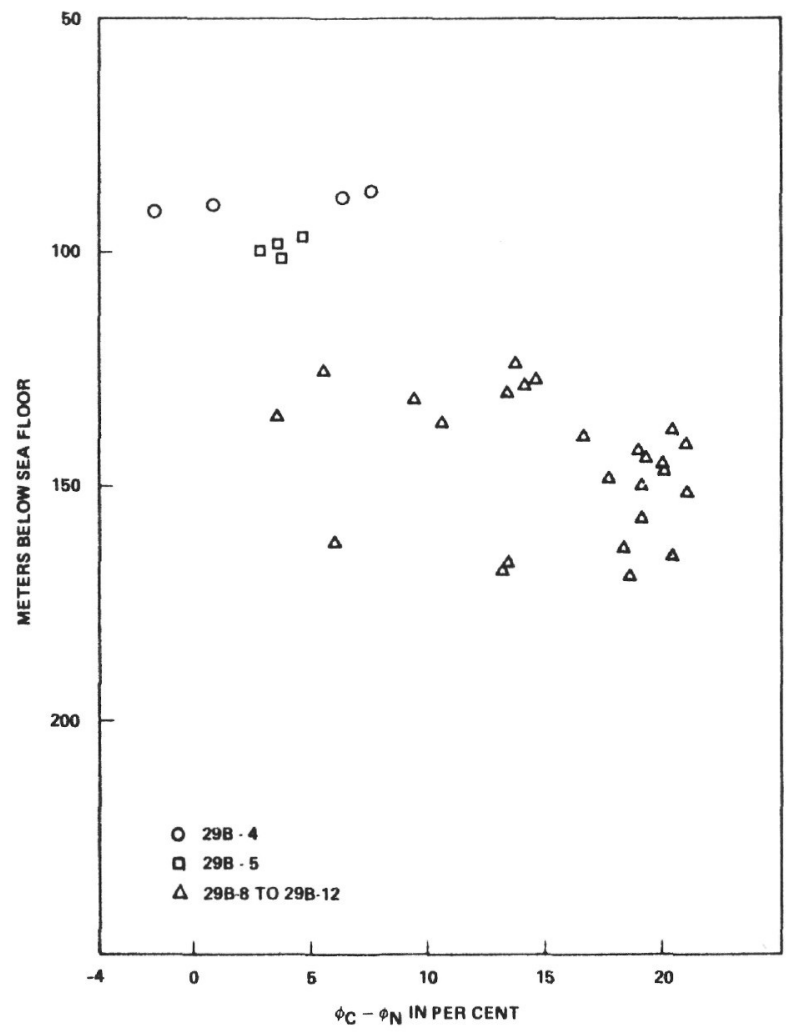

Figure 7. Difference between porosity of cores $\left(\phi_{C}\right)$ and in situ porosity $\left(\phi_{L}\right)$ as a function of depth (Site 29, Cores 29B-4, 29B-5 and 29B-8 to 29B-12).

The radiolarian ooze above the washed out zone indicates that layers having lower neutron porosity are more radioactive, but the correlation is poor.

\section{Gamma Ray Log}

An attempt to correlate the natural gamma radiation of the cores with in situ measurements was made. The natural gamma radiation measured on the cores should be representative of in situ conditions, except in cases where cores are extensively diluted (causing the gammaray values to be lower than those in situ) and in cases where the material is displaced in the section.

Three cores which appeared to be relatively undisturbed and which include material of both low and high radioactivity were selected for comparison with the logs: Core 29B-4 in a Lower Miocene-noncalcareous clay, Core 29B-5 in a Lower Miocene marl, and Core 29B-8 in an Upper Eocene radiolarian ooze. To correlate records, a rolling average was made of the core gammaray measurements using three measurements per average. The rolling averages were plotted at the same depth scale as the in-hole gamma-ray log. A best correlation between core and in situ measurements was sought and is shown on Figure 8. It can be seen that the correlation is only fair, but much better than expected considering the nature of the coring operation and the damaging effect it has on recovered materials.

Values of core gamma ray were plotted against corresponding values (as in Figure 8) of in situ measurements of gamma ray, and these are shown on Figure 9. The entire radiolarian ooze section is relatively uniform in radioactivity so that a minor miscorrelation between the core and log depths results in only a minor error and these values tend to cluster. However, the overlying Lower Miocene bedded sequence consists of different lithologies, and this fact makes correlation of core and in situ values tenuous for two reasons. First, the drilling techniques aboard the Glomar Challenger are such that in an alternating sequence of hard and soft beds, the hard beds tend to be recovered whereas the intervening soft ones sometimes are not. Core 29B-5 may contain examples of this; here the correlation between the core values and the log values is reasonably good with two exceptions: the interval from 4384.25 and 4384.75 meters on the gamma-ray log appears not to have been recovered in the coring sequence, and, also, Section 4 (1.5 meters) appears to be a compressed representation of the entire interval from 4388 to 4390.5 meters, an interval of 2.5 meters. Second, a relatively minor depth error in matching core and in situ measurements can result in a substantial error in the correlation of the values. The wide scatter in the correlation on Figure 9 confirms this. Note that the values from Core 29B-4 in the noncalcareous Lower Miocene clay are consistently more radioactive with respect to the in situ gamma ray than are the values from Core 29B-5 in the marl. Most of the more inconsistent values are in Section 2 and the upper part of Section 3 of 29B-5. In this interval the neutron log shows two more dense beds, each about 1.5 meters thick, interbedded with material that is either more porous or washed out. These beds may represent alternating less radioactive layers of more indurated marl having a lower clay content, and more radioactive layers of less indurated material with higher clay content. If the latter were lost selectively during the drilling process, the cores would be less radioactive than the in situ sequence, as is the case. Therefore, it is suggested that the section from Core 29B-5 is not representative of in situ conditions as far as gamma radiation is concerned.

Using a fit of the values from Cores 29B-4 and 29B-8:

$$
\gamma_{C}=1350+40.8 \gamma_{L}
$$

where $\gamma_{C}$ is the natural gamma radiation of the cores and is measured in counts per $3 \times 2.5$-inch core section per 1.25 minutes, and $\gamma_{L}$ is the natural gamma radiation 


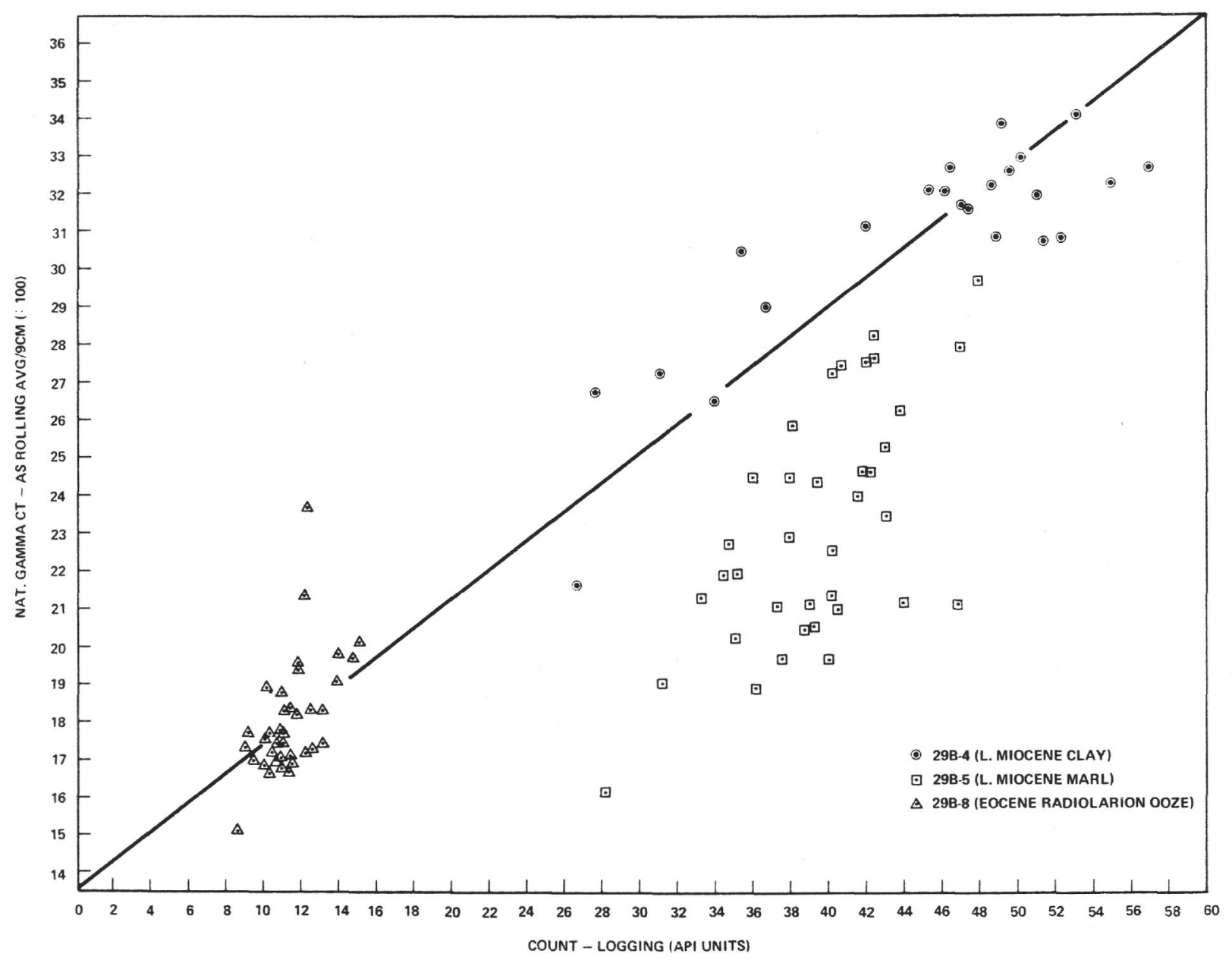

Figure 8. Correlation of measurements of gamma radiation of cores versus depth with in-situ gamma ray logs, (Site 29, cores 29B-4, 29B-5, and 29B-8).

measured in the hole with calibrated logging tools and is measured in A.P.I. units. A calibrated gamma ray logging tool indicates zero A.P.I. units in a non-radioactive pit. The background gamma ray count aboard the Glomar Challenger measured with no core in the counter, ranges widely depending on laboratory contamination and on the proximity of radioactive sources. At Site 29 the air background count ranged from 1365 to 1582 counts/ 1.25 minutes. The value of 1350 background counts derived from Figure 9 may be reasonably accurate for average laboratory conditions; the difference between this value and those measured when the counter is empty may represent the shielding effect of the core material itself.

In the Lower Miocene clay section the noncalcareous clay sampled by Core 29B-4 is markedly more radioactive than (46 to 57 A.P.I. units) the marl sampled by Cores 29B-5 and 29B-6 (26 to 48 A.P.I. units). The gamma-ray log shows a contact between the two lithologies at 4375 meters which may correspond to the contact at the bottom of Core 29B-4, Section 4. The sequence between this contact and 4396 meters (corrected) shows a series of more and less radioactive beds, and this variation in radioactivity is presumed to correspond to variation in carbonate content. Near the base of the Upper Miocene are two highly radioactive beds, each about two meters thick: one at 4396 meters (corrected) showing a maximum of 64 A.P.I. units, and one at 4400.5 meters (corrected) showing a maximum of 51 A.P.I. units. These radioactive beds probably correspond to the brown claystone sampled in Cores 29B-6 and 29B-7 which may mark periods of slow accumulation near the Eocene-Miocene boundary and which may contain abundant phosphate rich organic debris. The two beds are separated by a layer having low radioactivity probably corresponding to the chalk sampled by Core 29-7. 


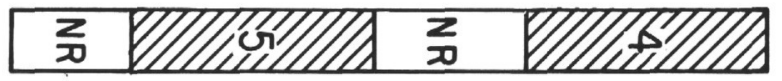

$S 7 \forall \wedge \forall \exists \perp N I$ $0 \exists$ व이 862

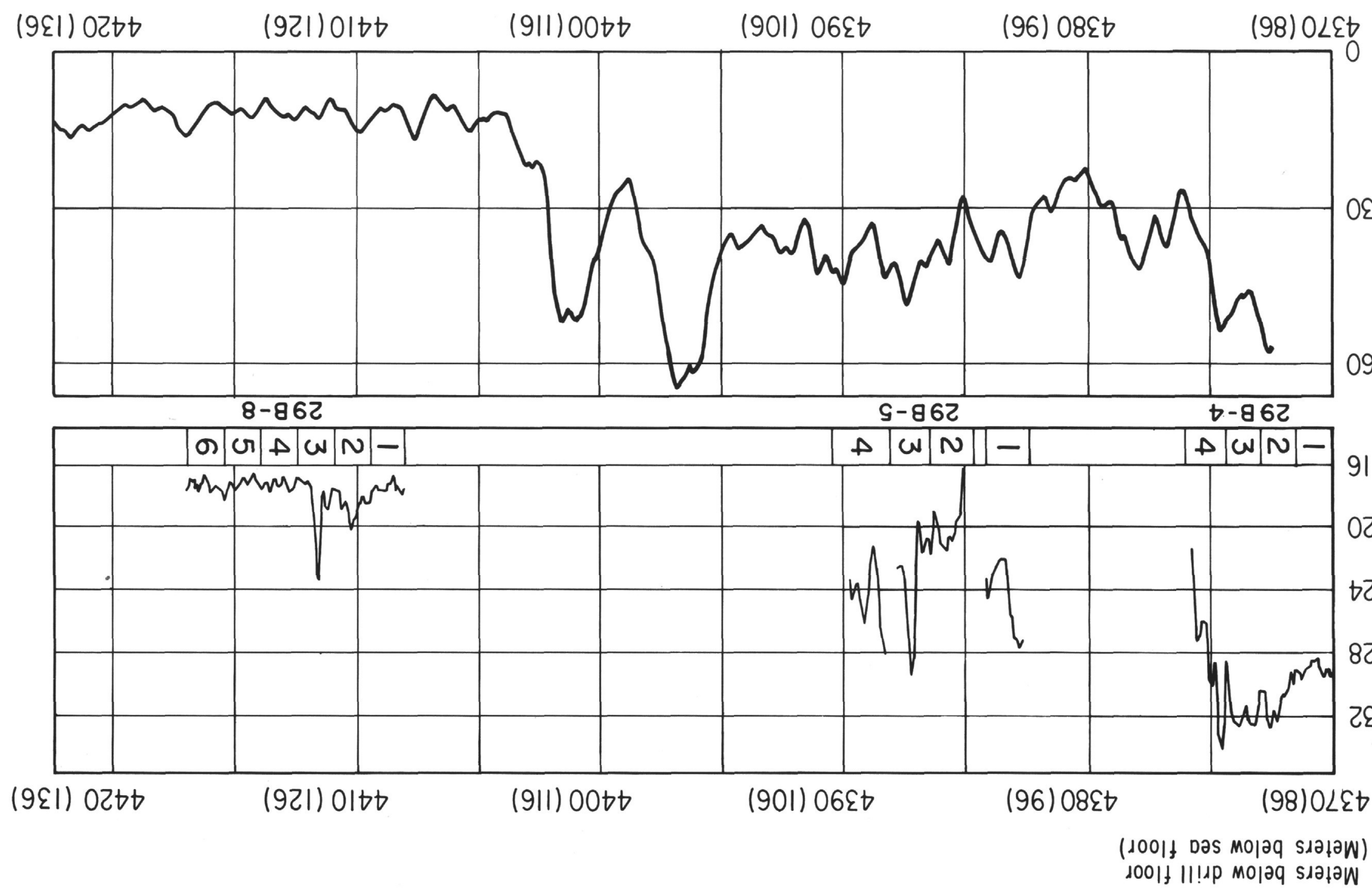

Figure 9. Relationship between measurements of gamma ray on cores and in situ by gamma ray logs, Site 29.
$D$
2
0
0
3

$O \varepsilon$

진

ज

09

$\widehat{ก}$

든

ज $D$

w $\frac{3}{3}$

$x=\frac{x}{D}$

$\sim 刃$

or $\frac{D}{x}$

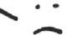

ำ

约

当 觉

$\frac{x}{0}$ N 
The radiolarian ooze which ranges in age from Middle to Upper Eocene and which was sampled by Hole 29 (Cores 8 through 18) and by Hole 29B (Cores 8 and 9), shows monotonously low radioactivity from 8 to 20 A.P.I. units throughout the entire 105 meters. The upper contact at 4402 meters (corrected) is prominent and the lower contact at 4511.5 meters (corrected) is visible on the gamma-ray log. The interval is slightly less radioactive in the upper part than in the lower, probably indicating a gradual decrease in clay content from middle to upper Eocene which may correspond to an increase in sedimentation rate.

The gamma-ray log shows that the top of the cherty dolomitic radiolarite, which terminated Holes 29, 29B and $29 \mathrm{C}$, is at 4512 meters (corrected). The radioactivity of the radiolarite is low (22 to 30 A.P.I. units), but somewhat higher than that of the overlying radiolarian ooze. Such data indicate the presence of a sediment with a concentration of clay component greater than that in the overlying radiolarian ooze. It was noted in the lithologic summary of Site 39 earlier in this volume that a considerable amount of sediment was lost in the process of coring the bottom of the hole. The in situ presence of considerable quantities of friable radiolarite lost in the process of coring would explain the gammaray $\log$ data.

\section{Electrical Survey Log}

The electrical survey log shows, essentially, three levels of resistivity: $0.95 \mathrm{ohm}$ meters ${ }^{2} /$ meter (16-inch normal) in the Lower Miocene noncalcareous pelagic clay, 0.85 ohm meter ${ }^{2}$ (16-inch normal) in the Lower Miocene marl, and $0.4 \mathrm{ohm}$ meters $^{2} /$ meter in the Eocene radiolarian ooze. The decreasing resistivity with depth probably marks an increase in the salinity of the pore water with depth.

When running the electrical survey log the operator dropped the tool to the total depth satisfactorily, but pulled up in order to verify the Self Potential with the current off on the normal and lateral curves. He then found it impossible to reach the total depth again, and the electric log is valid only to a depth of 4501 meters, which is above the Middle Eocene cherts.

There is a thin resistive streak in the radiolarian ooze section at 4408 meters, which shows a slight increase in radioactivity; together these factors would suggest that the layer may be unusually rich in carbonaceous organic matter.

\section{ELECTRICAL POTENTIAL GRADIENTS IN THE UP- PER MIXED LAYER OF THE CARIBBEAN AT SITE 31}

On March 21, 1969, the Glomar Challenger had just finished drilling in the central Caribbean area at Site 31, the last site in the Gulf-Atlantic-Caribbean portion of the Deep Sea Drilling Project. The ship was prepared to head for the Panama Canal to undertake the Pacific portion of her first expedition, but, after estimating the time and distance from Site 31 to Panama, the scientists calculated that there were approximately two hours of spare time. This, of course, was not sufficient time for additional deep-sea drilling, but did allow two short experiments: the first was an acoustical test of the dynamic positioning equipment; the second was an attempt to use standard oil well electrical logging equipment to examine possible gradients of electrical potential in the upper mixed layer of the ocean.

Accordingly, the Schlumberger E.S. logging tool was lowered on the sea cable through the drilling well in the center of the vessel. A lowering was made at a rate of 6 meters per minute ( 20 feet per minute) to 300 meters, measuring spontaneous potential between the \#2 bridle E.S. electrode (a lead wire electrode) and a seawater ground in the surface water alongside the ship. A recording was made on an oscillograph with 40 millivolts full scale. The record which was obtained showed little character, and was assumed to be largely noise. Upon reaching the 300-meter level, the electrical hookup was changed so that electrical potential could be measured between the electrode and the other leg of the measuring circuit grounded to the steel armor of the sea cable at a point 90 feet (27.5 meters) above the electrode. The circuit schematic is shown on the left side of Figure 10. On the right is shown a copy of the original record obtained while raising the instrument from the 300-meter level up to 50 meters. The depth, which is indicated on the oscillograph record, is the depth of the electrode.

Reading downward, the record trace shows an apparent sharp gradient with a number of spikes towards the minus side between 50 and 75 meters. Below this point the record appears to stabilize and then at 125 meters begins to show a sharp gradient, reaching a peak of 8 millivolts below the level recorded in the above section at 130 meters. The gradient reverses at this point and within five meters recovers to the earlier value. Then, with continued lowering, it stabilizes with a potential across the measuring interval about 2 millivolts below that indicated for the level 100 to 125 meters. At approximately 215 meters there is a gradual increase in the potential, a negative spike at 260 meters, and finally, for the region extending down to 300 meters, a stable situation with the electrical potential level higher than in any of the upper levels.

If, in fact, this measurement does represent a real feature in the ocean, the factors responsible could be important in studies of marine biology and, indirectly, to problems of sedimentation. The following discussion, based upon an analysis of this problematical measurement (Gerard, 1970), points to certain characteristics of the stratification that could, in some combination, lead to the observed pattern. 
SEA WATER SPONTANEOUS POTENTIAL

AT

SITE 31

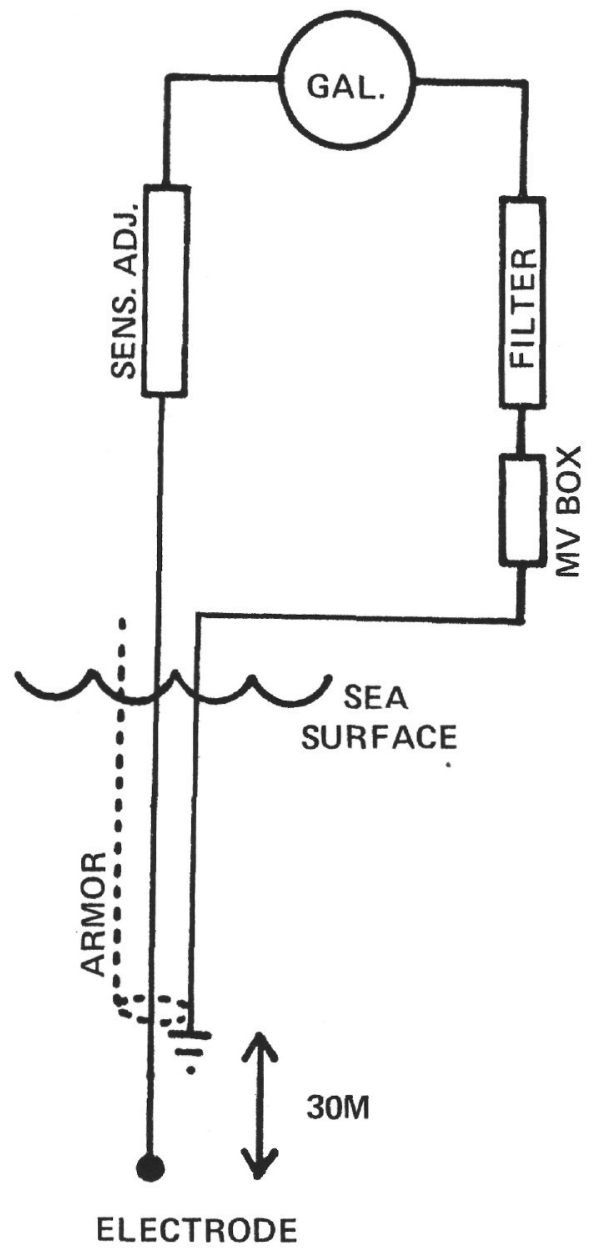

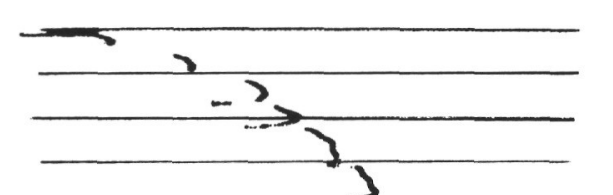

0050

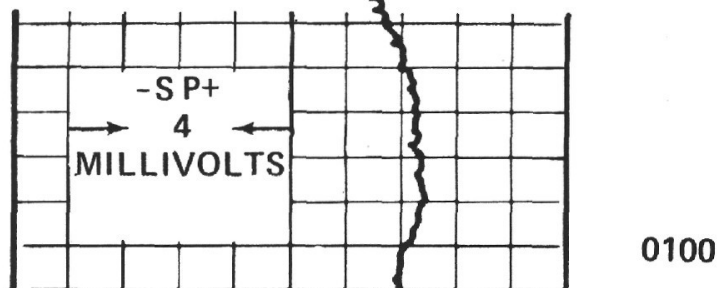

METERS DEPTH

0200

0250

Figure 10. Oscillograph record of spontaneous potential measurement at Site 31. A schematic diagram of this measuring circuit is shown on the left side of the figure. 
The vertical salinity-temperature distribution in the Caribbean (Wüst, 1964) shows a prominent subsurface salinity maximum found throughout the Caribbean basins at 150 meters. The salinity values, derived from standard hydrographic (Nansen bottle) observations and plotted for the "core" of this water are probably less than the actual salinity maxima at these sites. Figure 10 shows typical salinity-depth profiles for the Caribbean. Comparison of these profiles with electrical resistivity measurements in sea water (Thomas et al., 1934) suggests that the opposing strong gradients in salinity and temperature account for only a small or indifferent gradient of electrical resistivity above the salinity maximum, but a relatively strong gradient below the point where both gradients combine to increase resistivity.

The E-log electrodes used in borehole measurements by the oil industry commonly measure liquid junction potentials between drilling mud and saline formation waters. From the typical salinity-depth profiles in the Caribbean (Figure 11), the strongest gradient of salinity at the depth of the authors' observation $(1 \%$ per 100 meters) would correspond to about $0.3 \%$ across the 30-meter spacing of their electrodes. In this case, the expected potential which could be observed with ideal silver-silver chloride $(\mathrm{Ag} / \mathrm{AgCl})$ electrodes would be less than 0.2 millivolts and thus is alone inadequate to account for the approximately 8 millivolt deflection observed in our record (Figure 9).

Horizontally-towed electrodes (the GEK system) have been used to estimate surface ocean current velocities for more than twenty years (von Arx, 1950; LonguetHiggins et al., 1954). Horizontal gradients of electrical potential induced by the magnetic field of the earth, amounting to a few millivolts per hundred meters, are commonly measured. The near-surface current structure at DSDP Site 31 in the central Caribbean is not well known. Wüst (1964) shows an average (April) surface current velocity of 41 to $62 \mathrm{~cm} / \mathrm{sec}$, while Gordon (1967) indicates a velocity for the Subtropical Undercurrent of 11 to $20 \mathrm{~cm} / \mathrm{sec}$. Assuming the use of standard GEK electrodes (von Arx, 1950) used vertically in a manner corresponding to the authors' array, a current of about 10 knots $(515 \mathrm{~cm} / \mathrm{sec})$, alligned perpendicularly to the direction of the horizontal component of the earth's magnetic field, would be necessary to produce the observed potential.

Large internal waves could be expected just below the Caribbean Subtropical Underwater, where a sharp reduction in the density gradient occurs. Maclure et al. (1964) have measured significant induced magnetic fields at 100-meter depths in deep water off Vancouver Island due to long-period swell waves of 11 to 16 -second periods.
The puzzling measurement from the Glomar Challenger was submitted for appraisal to A. E. Worthington of Chevron Oil Field Research Company (Chairman of the JOIDES Well Logging Advisory Panel). He applied rigorous tests to the conjectural data and concluded, in agreement with the above estimates, that salinity gradients and geomagnetic potentials would be too small to create the observed effect, even with the most suitable electrodes. He pointed out, however, that the electrodes (one a lead wire and the other a copper wire in contact with the galvanized steel armor) were likely to be insensitive to the chloride ion concentration, but probably responsive to changes in the ratio of oxidized to reduced species in the medium, as well as to overall potential gradient. Worthington further pointed out that the nature of the electrodes and the records indicates that the electrodes are not symmetrical and that the upper one, composed of a couple of divalent metals, could well be sensitive to redox potentials and could alone be responsible for the most prominent effects shown on the record. The above reasoning requires shifting the depth of the event, shown on the record at 130 meters, to about 100 meters (the difference representing electrode spacing) to coincide with the depth of the upper electrode.

A hydrographic station (Figure 12), taken in the central Caribbean at the same season as DSDP Site 31, reveals a sharp decrease in temperature coincident with a strong gradient of increasing salinity just above the salinity maximum, resulting in a strong density gradient or pycnocline at the base of the upper mixed layer (100 to 150 meters). Data obtained from five biologicalhydrographical stations in the Virgin Island Basin in 1967 (Wood, unpublished data) show a large increase in the absolute number of phytoplankton cells at a depth coincident with the upper portion of the pycnocline (60 to 100 meters). The peak in the phytoplankton count increases sharply in the maximum level, and is typically 20 to 50 times that in the levels only 20 meters above and below. If this (presumably live) population should die off, bacterial action could quickly deplete the oxygen in this narrow zone, and the extreme stability of the layer could retain this effect over a considerable time and space.

The strong stability in the pycnocline zone is comparable to the critical values of $\Delta \sigma_{t} / \Delta \mathrm{Z}$ shown by Richards and Vaccaro (1956) as necessary to impose sufficient restraint on vertical circulation across the sill depths of certain basins to permit anoxic conditions to develop below. The stability (approximated by the sigma-t gradient, $\left.\Delta \sigma_{\mathrm{t}} / \Delta \mathrm{Z} \times 10^{-3} \mathrm{~m}^{-1}\right)$ in the 100 to 150 meter zone at Atlantis Station 1510 is $3.01 \times 10^{-5}$, a value comparable to that in the sill depth of the Cariaco Trench, an anoxic basin in the southern Caribbean. Richards (1965) shows values of redox potential oxygen and sulphide concentration in the Black Sea which 


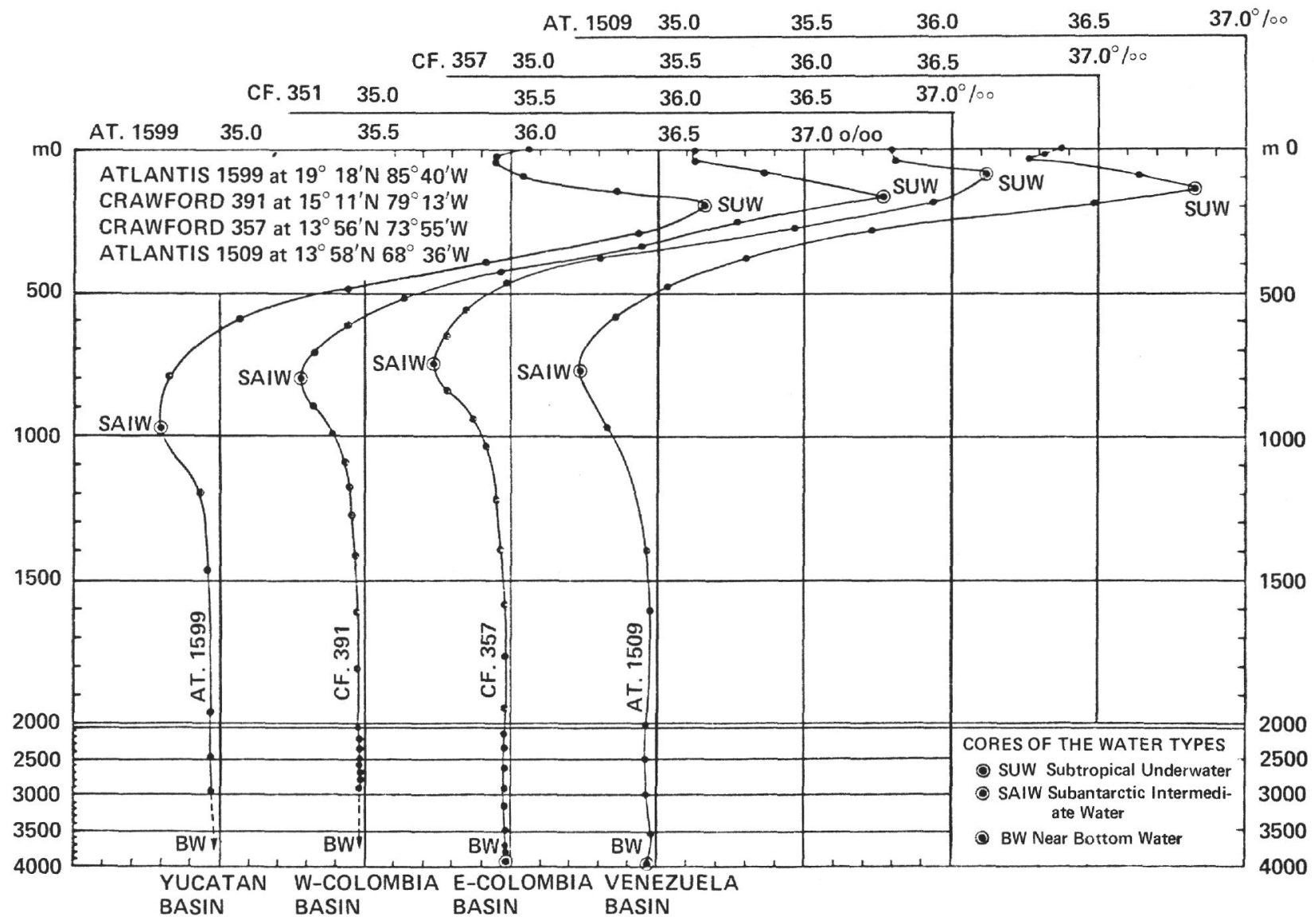

VERTICAL DISTRIBUTION OF SALINITY AT FOUR STATIONS OF ATLANTIS (1933) AND CRAWFORD (1958) IN THE CARIBBEAN BASINS

Figure 11. Vertical distribution of salinity at four stations of ATLANTIS (1933) and CRAWFORD (1958) in the Caribbean basins (from Wust). 


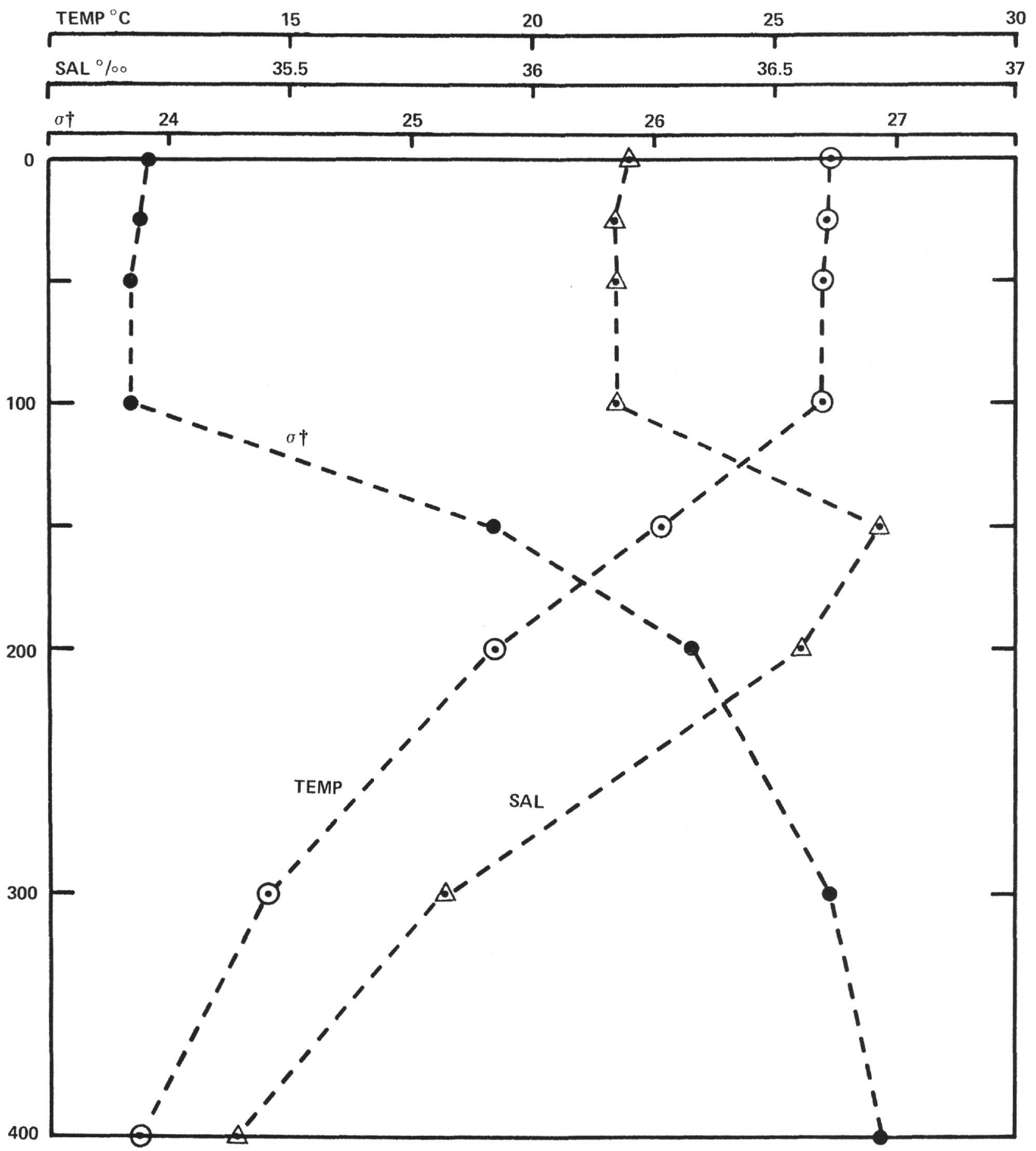

Figure 12. ATLANTIS Hydrographic Station $\# 1510-14^{\circ} 54^{\circ} \mathrm{N}, 68^{\circ} 33^{\prime} \mathrm{W}$; showing measurements of temperature, salinity and sigma-t plotted against depth. 
indicate a sharp decrease in redox potential in the zone at 100 to 150 meters, where oxygen values drop near zero and sulphides appear.

If the problematical single measurement is, in fact, a response to a thin (10-meter) oxygen depleted layer at the top of the pynocline, why has this effect not been observed before? Figure 11 illustrates the vertical sample spacing in a typical hydrographic station. The chance that such a thin layer might be sampled is small indeed, and it is unlikely that a chemical oceanographer would accept the anomalously low oxygen value of such a sample.

There appear to be no examples of profiles of dissolved oxygen in this region of the Caribbean taken with the continuously-recording oxygen electrode probe. However, profiles taken in this manner could easily miss such a feature because of its narrow vertical extent and the relatively long time constant (6 to 20 seconds) of the sensor.

There is a strong possibility that the single record of spontaneous potential discussed above is only a measure of spurious noise, and that the apparent strong anomaly at the depth of the pycnocline is a mere coincidence. The lack of controls and numerous uncertainties associated with this measurement make speculations hazardous and conclusions unwarranted. For example, the authors do not know the nature of the electrical field associated with the ship, the cell constants of the measuring equipment, the telluric currents in the sea (Bogdanov and Ivanov, 1960), the vertical gradients of ocean currents, the electrical consequences of gradients of temperature, salinity, dissolved gases and ocean currents, or the electrical effects of internal waves in the stratified upper layers of the ocean.

The important point to be made is that scientists have essentially no background against which to evaluate a measurement of this nature. It is hoped that the questions raised by this experiment will stimulate discussion on the problems of well logging at deep ocean drill sites and prospects of electrical profile measurements in the oceans which may relate indirectly to problems of sedimentation.

\section{REFERENCES}

Abernathy, S. H., 1965. Improved equipment for a pulse method of sound velocity measurement in water, rock, and sediment. U. S. Navy Electronics Laboratory, San Diego, California, Technical Memorandum-824.

Arrhenius, G. O. S., 1963. Pelagic sediments. In The Sea. M.N. Hill (Ed.). New York (Interscience) 3, 655.

Bogdanov, M. A. and Ivanov, Ur. A., 1960. Electric currents in the sea and the measurement of sea currents with an electromagnetic device. Tr. Inst. Okeanol.
Akad. Nauk SSSR. 39. (Translation by Israel Prog. for Scientific Translations, CFSTI \#TT68-50356 pp. 75-78, 1968).

Bramlette, M. N., 1961. Pelagic sediments. In Oceanography. M. Sears (Ed.). Washington, D. C. (AAAS Publication) 345.

Brier, C., Bennin, R. and Rona, P. A., 1969. Preliminary evaluation of a core scintillation counter for bulkdensity measurement in marine sediment cores. $J$. Sediment. Petrol. 39 (4), 1509.

Doig, Ronald, 1968. The natural gamma-ray flux: in situ analysis. Geophysics. 32 (2), 311.

Dewan, J. T., 1956. Neutron log correction charts for borehole conditions and bed thickness. Trans., AIME. 207,50 .

Evans, H. B. and Cotterel, C. H., 1968. Gamma-ray attenuation density scanner. In DSDP Core Description Manual. Part V: Shipboard Treatment of Cores. Unpublished technical manual.

Evans, H. B., Lucia, J. A. et al., 1968. Natural gammaray core scanner. In DSDP, Core Description Manual. Part V: Shipboard Treatment of Cores. Unpublished technical manual.

Gerard, R. (in press). A problematical measurement of electrical potential in the upper 300 meters of the Central Caribbean. Marine Tech. Soc. Symp.: Trans. Elec. Measure. Chem. Prop. Sea Water. 1970.

- 1964. Caribbean current measurements. Lamont Geological Observatory Technical Report \#CU-2663-14, 1-16 (unpublished).

Gordon, Arnold, L., 1967. Circulation of the Caribbean Sea.J. Geophys. Res. 72, 6207.

Griffin, J. J. and Goldberg, E. D., 1963. Clay-mineral distribution in Pacific Ocean. In The Sea. M. N. Hill (Ed.). New York (Interscience) 3, 728.

Hamilton, E. L., 1956. Low sound velocities in high porosity sediments. J. Acoust. Soc. Am. 28, 16.

, 1959. Thickness and consolidation of deep sea sediments. Bull. Geol. Soc. Am. 70, 1399.

, 1960. Ocean basin ages and amounts of original sediments. J. Sediment. Petrol, 30, 370.

1964. Consolidation characteristics and related properties of sediments from experimental Mohole (Guadalupe Site). J. Geophys. Res. 69 (20), 4257.

, 1969. Sound velocity, elasticity, and related properties of marine sediments, North Pacific. Naval Undersea Research and Development Center. Vols. I-III.

Hamilton, E. L., Shumway, G., Menard, H. W. and Shipek, C. J., 1956. Acoustic and other physical properties of shallow-water sediments off San Diego. J. Acoust. Soc. Am. 28, 1.

Horn, D. R., Horn, B. M. and Delach, M. N., 1968. Sonic properties of deep-sea cores from the north Pacific basin and their bearing on the acoustic provinces of the north Pacific. Technical Rept. \#10, CU-10-68 NAVSHIPS N00024-67-C-1186, December 1968 . 
Ingelman, K. R. and Hamilton, E. L., 1963. Bulk densities of mineral grains from Mohole samples (Guadalupe Site). J. Sediment. Petrol. 33, 474.

Koczy, F. F. and Rosholt, J. N., 1962. Radioactivity, in oceanography. In Nuclear Radiation in Geophysics. H. Israel and A. Krebs (Eds.). Berlin (SpringerVerlag) 18.

Laughton, A. S., 1954. Laboratory measurements of seismic velocities in ocean sediments. Proc. Roy. Soc. London, A. 222, 336.

, 1957. Sound propagation in compacted ocean sediments. Geophysics. 22, 233.

Longuet-Higgins, M. S., Stern, M. E. and Stommel, H., 1954. The electrical field induced by ocean currents and waves, with applications to the method of towed electrodes. Papers Phys. Oceanogr. Meteor. 13, 1.

Lynch, E. J., 1962. Formation Evaluation. New York (Harper and Row) 422.

Maclure, K. C., Hafer, R. A. and Weaver, J. T., 1964. Magnetic variations produced by ocean swell. Nature. 204, 1290.

Moore, D. G., 1964. Shear strength and related properties of sediments from experimental Mohole (Guadalupe Site). J. Geophys. Res. 69, 4271.

Nafe, J.E. and Drake, C.L., 1957. Variation with depth in shallow and deep water marine sediments of porosity, density and the velocities of compressional and shear waves. Geophysics. 22, 523.

1963. Physical properties of marine sediments. In The Sea. M.N. Hill (Ed.). New York (Interscience) 3, 794.

Prospero, J. M. and Koczy, F. F., 1966. Radionuclides in oceans and sediments. In Encyclopedia of
Oceanography. R. W. Fairbridge (Ed.). New York (Reinhold Publishing Corp.) 730.

Ratcliffe, E. H., 1960. The thermal conductivity of ocean sediments. J. Geophys. Res. 65, 1535.

Richards, F. A., 1965. Anoxic Basins and Fjords. In Chemical Oceanography. J. P. Riley and G. Skirrow (Eds.). New York (Academic Press) 1, 635.

Richards, F. A. and Vaccaro, R. F., 1956. The Cariaco Trench, an anaerobic basin in the Caribbean Sea. Deep-Sea Res. 3, 214.

Schlumberger, 1966. Log Interpretation Principles. Schlumberger (Ed.). Paris (Keeran-Servant).

Sutton, G. H., Berckheimer, H. and Nafe, J. E., 1957. Physical analysis of deep sea sediments. Geophysics. 22, 779 .

Thomas, B. D., Thompson, T. G. and Utterback, C. L., 1934. The electrical conductivity of sea water. $J$. Cons. Int. Expl. Mer. 9, 28-35.

von Arx, W. S., 1950. An electromagnetic method for measuring the velocities of ocean currents from a ship under way. Papers Phys. Oceanogr. Meteor. 2, 1.

von Herzen, R. P. and Maxwell, A. E.; 1959. The measurement of thermal conductivity of deep-sea sediments by a needle-probe method. J. Geophys. Res. 64, 1557.

Winokur, R. S. and Chanesman, S., 1966. A pulse method for sound speed measurements in cored ocean bottom sediments. U. S. Naval Oceanographic Office, I. M. 66-5. 10.

Wüst, G., 1964. Stratification and Circulation in the Antillian-Caribbean Basins, Part One - Spreading and Mixing of the Water Types. New York (Columbia University Press) 7, 67. 